Supporting Information

\title{
A Long $\pi$-Conjugated Poly-para-Phenylene-Based Polymeric Segment of Single-Walled Carbon Nanotubes
}

Qiang Huang, ${ }^{\text {ta }}$ Guilin Zhuang, ${ }^{\text {tb }}$ Mengmeng Zhang, ${ }^{\text {a Jinyi Wang, }}{ }^{\text {a }}$ Shengda Wang, ${ }^{a}$ Yayu $\mathrm{Wu},{ }^{a}$ Shangfeng Yang, ${ }^{\text {a }}$ Pingwu $\mathrm{Du}^{* a}$

${ }^{a}$ Hefei National Laboratory for Physical Sciences at the Microscale, CAS Key Laboratory of Materials for Energy Conversion, Department of Materials Science and Engineering, $i$ ChEM, University of Science and Technology of China (USTC), 96 Jinzhai Road, Hefei, Anhui Province, 230026, P. R. China. ${ }^{b}$ College of Chemical Engineering, Zhejiang University of Technology, 18, Chaowang Road, Hangzhou, Zhejiang Province 310032, P. R. China.

*Corresponding author: dupingwu@ustc.edu.cn

Tel/Fax: 86-551-63606207 


\section{Materials and General Information}

High resolution mass spectrometry (HR-MS) analyses were carried out using MALDITOF-MS techniques. Samples were characterized with infrared spectroscopy (IR, FTS7000, Varian, USA) and Raman spectroscopy (RM3000, Renishaw, UK). NMR spectra were recorded on Bruker BioSpin $\left({ }^{1} \mathrm{H} 400 \mathrm{MHz},{ }^{13} \mathrm{C} 100 \mathrm{MHz}\right)$ spectrometer, and chemical shifts were reported as the delta scale in ppm relative to $\mathrm{CDCl}_{3}(\delta=7.26 \mathrm{ppm})$ for ${ }^{1} \mathrm{H}$ NMR and $\mathrm{CDCl}_{3}(\delta=77.0 \mathrm{ppm})$ for ${ }^{13} \mathrm{C}$ NMR. Data are reported as follows: chemical shift, multiplicity $(\mathrm{s}=$ singlet, $\mathrm{d}=$ doublet, $\mathrm{t}=$ triplet, $\mathrm{m}=$ multiplet $)$, coupling constant $(\mathrm{Hz})$, and integration. UV-vis absorption spectra were performed on a UNIC3802 spectrophotometer. All solvents for syntheses were dried by distillation under nitrogen prior to use (tetrahydrofuran (THF) and 1,4-dioxane were distilled after reflux with sodium). Other chemicals were obtained from commercial suppliers (Innochem or Acros). Air-sensitive reactions were all carried out under argon. The molecular weight distribution, relative number-average and weight-average molecular weights were determined at $40{ }^{\circ} \mathrm{C}$ by gel permeation chromatography (GPC, Waters 1515) equipped with a refractive index detector (Waters 2414) and a series of Styragel $\mathrm{HR}_{1}, \mathrm{HR}_{3}$ and $\mathrm{HR}_{5}$ (DMF) column with the eluent at $1.0 \mathrm{~mL} / \mathrm{min}$. The calibration was built on polystyrene standards. The Raman spectra for the solid samples of $\mathbf{8}$ and PS1 were acquired under ambient conditions. A He-Ne laser $(633 \mathrm{~nm})$ was utilized with the incident power limited to as low as $20 \mathrm{uW}$. 


\section{Synthetic procedures}

\section{Synthesis of 2,2'-(2,5-dibromo-1,4-phenylene)bis(4,4,5,5-tetramethyl-1,3,2-}

dioxaborolane) (2). The material 2 was synthesized according to literature reports. ${ }^{\mathrm{S} 1}$

Synthesis of 2',5'-dibromo-4,4'-dichloro-1,1':4',1"'-terphenyl (4). To a mixture of 2

(2 g, $4.0 \mathrm{mmol})$ and 1-chloro-4-iodobenzene 3 (2.3 g, $9.6 \mathrm{mmol})$ dispersed in toluene $(30 \mathrm{~mL})$ and deionized water $(3 \mathrm{~mL})$ in a round-bottom flask $(250 \mathrm{~mL})$ was added tetrabutylammonium bromide (TBAB, $220 \mathrm{mg}, 0.68 \mathrm{mmol}$ ), then degassed for 15 minutes by bubbling Ar through the solution. To the mixture were added tetrakis(triphenylphosphine)palladium $(300 \mathrm{mg}, 0.26 \mathrm{mmol})$ and $\mathrm{K}_{2} \mathrm{CO}_{3}(3 \mathrm{~g}, 21.7$ mmol), which was further purged with Ar for another 15 minutes. Thereafter, the mixture was then stirred at $80{ }^{\circ} \mathrm{C}$ for $24 \mathrm{~h}$, the reaction was quenched with methanol (10 mL). The crude product was recrystallization from $\mathrm{CH}_{2} \mathrm{Cl}_{2} / \mathrm{MeOH}$ to afford 4 as white solid (1.48 g, 60\%). ${ }^{1} \mathrm{H}$ NMR $\left(\mathrm{CDCl}_{3}, 400 \mathrm{MHz}\right): \delta(\mathrm{ppm}) 7.61(\mathrm{~s}, 2 \mathrm{H}), 7.43(\mathrm{~d}$, $J=8.4 \mathrm{~Hz}, 4 \mathrm{H}), 7.37(\mathrm{~d}, J=8.4 \mathrm{~Hz}, 4 \mathrm{H}) ;{ }^{13} \mathrm{C} \mathrm{NMR}\left(\mathrm{CDCl}_{3}, 100 \mathrm{MHz}\right): \delta(\mathrm{ppm}) 128.47$, 130.60, 134.36, 135.12, 137.07, 142.03. IR (KBr) cm $\mathrm{cm}^{-1}: 1906,1777,1594,1500,1462$, 1399, 1337, 1299, 1229, 1180, 1092, 1022, 1003, 957, 895, 847, 821, 745, 718.

Synthesis of $2,2^{\prime}-\left(4,4^{\prime \prime}\right.$-dichloro-[1,1':4',1'-terphenyl]-2',5'-diyl)bis $(4,4,5,5$ tetramethyl-1,3,2-dioxaborolane) (5). A 50-mL flask containing 4 (1 g, $2.2 \mathrm{mmol})$, $\operatorname{Pd}($ dppf $) \mathrm{Cl}_{2} \quad(170 \mathrm{mg}, 208 \mu \mathrm{mol})$, dried KOAc (1.52 g, $\left.11.0 \mathrm{mmol}\right)$, and bis(pinacolato)diboron $(2.26 \mathrm{~g}, 8.8 \mathrm{mmol})$, and the flask was evacuated and filled with argon three times, dry 1,4-dioxane $(10 \mathrm{~mL})$ was transferred to the flask via syringe under nitrogen at room temperature. The mixture was then stirred at $90{ }^{\circ} \mathrm{C}$ for $24 \mathrm{~h}$, the reaction was quenched with methanol $(40 \mathrm{~mL})$. The crude product was recrystallization from $\mathrm{CH}_{2} \mathrm{Cl}_{2} / \mathrm{MeOH}$ to afford 5 as white solid (1.0 g, yield $\left.85 \%\right) .{ }^{1} \mathrm{H}$ NMR $\left(\mathrm{CDCl}_{3}\right.$, 
$400 \mathrm{MHz}): \delta(\mathrm{ppm}) 7.67$ (s, 2H), $7.36(\mathrm{~s}, 8 \mathrm{H}), 1.21(\mathrm{~s}, 24 \mathrm{H}) ;{ }^{13} \mathrm{C} \mathrm{NMR}\left(\mathrm{CDCl}_{3}, 100\right.$ MHz): $\delta$ (ppm) 144.45, 141.28, 135.13, 132.95, 130.55, 127.77, 83.96, 24.58. HR-MS (MALDI-TOF) $m / z$ calcd. for $\mathrm{AgC}_{76} \mathrm{H}_{62} \mathrm{O}_{6}[\mathrm{M}]^{+}:$657.1071, found: 657.1057. IR (KBr) $\mathrm{cm}^{-1}: 2980,2932,1595,1507,1480,1410,1388,1378,1327,1298,1270,1243,1213$, $1172,1141,1105,1088,1033,1012,964,910,857,833,815,745,725$.

Synthesis of compound 7. To a degassed suspension of $\mathbf{6}^{\mathrm{S} 2}(175.7 \mathrm{mg}, 0.2 \mathrm{mmol}), \mathbf{1 0}$ (110 mg, $0.2 \mathrm{mmol})$, and $\mathrm{KOH}(260 \mathrm{mg}, 1.88 \mathrm{mmol})$ in THF (136 mL) and $\mathrm{H}_{2} \mathrm{O}(14$ $\mathrm{mL})$ was added $\mathrm{Pd}\left(\mathrm{PPh}_{3}\right)_{4}(10 \mathrm{mg}, 0.014 \mathrm{mmol})$, then the mixture was degassed for 30 min. The mixture was then heated up to $80^{\circ} \mathrm{C}$ for $48 \mathrm{~h}$ under nitrogen atmosphere. After cooling down to room temperature, water was added and the mixture was extracted with DCM. The combined organic layer was dried over anhydrous $\mathrm{MgSO}_{4}$, filtered and concentrated under reduced pressure to afford crude product 7 as a white solid for the next step without further purification.

Synthesis of 8. To a 50-mL round-bottom flask (vessel A) containing a magnetic stirring bar were added $\mathrm{SnCl}_{2} \cdot 2 \mathrm{H}_{2} \mathrm{O}(305 \mathrm{mg}, 1.3 \mathrm{mmol})$, THF $(25 \mathrm{~mL})$ and concentrated $\mathrm{HCl} / \mathrm{H}_{2} \mathrm{O}(0.23 \mathrm{ml}, 12 \mathrm{~mol} / \mathrm{L})$ were added, and the resultant mixture was further stirred at room temperature for $30 \mathrm{~min}$. To another $200-\mathrm{mL}$ round-bottom flask (vessel B) containing a magnetic stirring bar were added the above crude product 7 and dry THF $(10 \mathrm{~mL})$. A solution of $\mathrm{H}_{2} \mathrm{SnCl}_{4} / \mathrm{THF}(18 \mathrm{~mL}, 0.72 \mathrm{mmol}, 0.04 \mathrm{M}$ in THF) in vessel A was added. After stirring the mixture at at room temperature for $2 \mathrm{~h}$, the mixture was quenched with aqueous sodium hydroxide, extracted with $\mathrm{CH}_{2} \mathrm{Cl}_{2}$, dried over $\mathrm{Na}_{2} \mathrm{SO}_{4}$, and concentrated under reduced pressure. The crude product was purified by column chromatography (hexane/ $\left.\mathrm{CH}_{2} \mathrm{Cl}_{2}=4 / 1\right)$ to afford 8 (16.6 mg, $\sim 10 \%$ over two steps) as a yellow solid. ${ }^{1} \mathrm{H} \mathrm{NMR}\left(\mathrm{CDCl}_{3}, 400 \mathrm{MHz}\right): \delta(\mathrm{ppm}) 7.53-7.46(\mathrm{~m}, 16 \mathrm{H}), 7.32$ $(\mathrm{d}, J=8.4 \mathrm{~Hz}, 4 \mathrm{H}), 7.23-7.22(\mathrm{~s}, 2 \mathrm{H}), 7.22-7.16(\mathrm{~m}, 8 \mathrm{H}), 7.04(\mathrm{~d}, J=8.4 \mathrm{~Hz}, 4 \mathrm{H}), 6.98$ 
$(\mathrm{d}, J=8.8 \mathrm{~Hz}, 4 \mathrm{H}) ;{ }^{13} \mathrm{C} \mathrm{NMR}\left(\mathrm{CDCl}_{3}, 100 \mathrm{MHz}\right): \delta 127.18,127.25,127.36,127.53$, $127.57,127.88,128.30,130.51,130.78,132.33,133.19,137.53,137.54,137.70$, 137.80, 138.05, 138.36, 138.40, 138.82, 139.00, 139.53 . HR-MS (MALDI-TOF) $\mathrm{m} / \mathrm{z}$ calcd. for $\mathrm{C}_{60} \mathrm{H}_{38} \mathrm{Cl}_{2}[\mathrm{M}]^{+}$: 828.2354, found: 828.2350. IR (KBr) $\mathrm{cm}^{-1}$ : 2924, 2851, $1900,1644,1586,1479,1388,1263,1090,904,817,725$. Raman spectra $\left(\mathrm{cm}^{-1}\right): 1202$, $1262,1503,1582$.

Synthesis of PS1. To a mixture of 8 (54 mg, 65.1 umol), 2,2'-bipyridyl (119 mg, 0.76 $\mathrm{mmol})$, and 1,5-cyclooctadiene (94 ul, $0.76 \mathrm{mmol})$ in a round-bottom flask $(25 \mathrm{~mL})$ was added anhydrous DMF/toluene ( $5 \mathrm{~mL} / 5 \mathrm{~mL})$. The mixture was bubbled with Ar for 0.5 $\mathrm{h}$ before bis(1,5-cyclooctadiene)nickel(0) $(210 \mathrm{mg}, 0.763 \mathrm{mmol})$ was added in one portion. Thereafter, the mixture was heated up to reflux for $96 \mathrm{~h}$ to give a deep purple suspension. Upon cooling to room temperature, the solvent was removed by rotary evaporator. The crude product was washed with methanol, filtered and washed with water, $0.5 \mathrm{M} \mathrm{HCl}$ solution in water, water, $0.5 \mathrm{M} \mathrm{NaOH}$ solution in water, water, methanol, acetone, methanol, and hexane. The precipitate was collected, giving $43 \mathrm{mg}$ of polymer PS1 as a yellow solid (yield: $87 \%$ ): $\mathrm{M}_{\mathrm{n}}=16900 \mathrm{~g} \cdot \mathrm{mol}^{-1}, \mathrm{M}_{\mathrm{w}}=24300 \mathrm{~g} \cdot \mathrm{mol}^{-}$

${ }^{1}$ by GPC. ${ }^{1} \mathrm{H}$ NMR $\left(\mathrm{CDCl}_{3}, 400 \mathrm{MHz}\right): \delta(\mathrm{ppm})$ 7.56-7.36 (br), 7.35-7.23 (br), 7.227.02 (br). IR (KBr) cm $\mathrm{cm}^{-1}: 3021,2948,2925,2852,1896,1644,1582,1480,1465,1386$, 1260, 1002, 817, 727. Raman spectra $\left(\mathrm{cm}^{-1}\right):$ 1202, 1264, 1280, 1505, 1582, 1602.

\section{Photophysical studies}

UV-Vis absorption spectra of PS1 and monomer 8 were performed on a UNIC-3802 
spectrophotometer at room temperature. The fluorescent emission experiments were performed on a Fluoromax-4 spectrofluorometer at room temperature. The fluorescence spectra of PS1 and $\mathbf{8}$ were collected under an excitation wavelength at $331 \mathrm{~nm}$ and 337 $\mathrm{nm}$, respectively. The fluorescent time-resolved decays were measured on a Mini-tau spectrometer (Edinburgh, U.K.) using time-correlated single-photon counting technique (TCSPC). The sample was excited at $390 \mathrm{~nm}$ with a picosecond pulsed diode laser (EPL-390, Edinburgh, U.K.) triggered at $5 \mathrm{MHz}$ repetition rate. The emission was detected at $534 \mathrm{~nm}$. The detected fluorescence intensity decays were analyzed using a monoexponential model. The measurements were performed at least twice for consistency. PS1 and monomer $\mathbf{8}$ were measured in $\mathrm{CH}_{2} \mathrm{Cl}_{2}$ with a concentration of 1.0 $\times 10^{-5} \mathrm{M}$ and $0.1 \mathrm{mg} \cdot \mathrm{mL}^{-1}$, respectively.

\section{The Scholl reaction for monomer 8 and PS1}

To see if the neighboring phenylene rings on the main-chain of PS1 can be fused, we performed the Scholl oxidation using monomer $\mathbf{8}$ as a model reaction (Figure S15a). After the reaction, it was found that the neighboring phenylene rings on the main-chain and on the macrocycle are not fused by mass spectrometry analysis (Figure S15b). We have also performed the Scholl oxidation for PS1 (Figure S16a). Similarly, no evidences showed that the neighboring phenylene rings on the main-chain and on the macrocycle are fused and the UV-vis absorption spectra have no significant differences before and after the reaction (Figure S16b). This is probably because the Scholl reaction mechanism is very different between a planar precursor and a nonplanar precursor. 


\section{Solid-state packing study}

The wide-angle X-ray diffraction (WAXD) pattern of PS1 at $25^{\circ} \mathrm{C}$ is shown in Figure S28a. We found that it has several diffraction rings, indicating that the polymer has a certain crystallinity, but with low orientation. The Corresponding 1D WAXD intensity curve of PS1 (Figure S28b) shows broad peaks at 23.0 and $30.5^{\circ} \mathrm{C}$, which correspond to d spacings at 3.9 and $2.9 \AA$, respectively. This crystalline packing could also contribute to its charge transporting properties.

\section{The electron-only ITO/ZnO/PS1/Ca/Al device}

For the SCLC measurements, electron-only devices (ITO/ZnO/PS1/Ca/Al) were fabricated as follows: $0.1 \mathrm{M}$ zinc acetate in a solution mixture of 2-methoxy ethanol and ethanolamine was spin-coated onto the ITO substrates at $3000 \mathrm{rpm}$ for $30 \mathrm{~s}$, followed by heating at $200{ }^{\circ} \mathrm{C}$ for $30 \mathrm{~min}$ in air to form a $\mathrm{ZnO}$ film. The odichlorobenzene solution of PS1 (5 mg/ml) was spin-coated onto the ZnO layer at 1000 $\mathrm{rpm}$ for $40 \mathrm{~s}$, and the devices were annealed at $125^{\circ} \mathrm{C}$ for $10 \mathrm{~min}$. Finally, $10 \mathrm{~nm} \mathrm{Ca} / 80$ $\mathrm{nm} \mathrm{Al}$ was deposited sequentially atop the active layer in a vacuum chamber $\left(\sim 10^{-5} \mathrm{~Pa}\right)$ with a defined active area of $2 \times 5 \mathrm{~mm}^{2}$.

\section{The hole-only ITO/PSS/PS1/MoO3/Ag device}

For the SCLC measurements, hole-only devices (ITO/PEDOT: PSS/PS1/MoO$/ / \mathrm{Ag}$ ) were fabricated as follow: ITO was treated in an ultraviolet-ozone chamber for $15 \mathrm{~min}$. Then PEDOT: PSS was spin-coated onto the ITO substrates at $3500 \mathrm{rpm}$ for $40 \mathrm{~s}$ and 
was heated at $150^{\circ} \mathrm{C}$ for $15 \mathrm{~min}$. The o-dichlorobenzene solution of PS1 (5 mg/ml) was spin-coated onto the PEDOT: PSS layer at $1000 \mathrm{rpm}$ for $40 \mathrm{~s}$, and the devices were annealed at $125{ }^{\circ} \mathrm{C}$ for $10 \mathrm{~min}$. Finally, $8 \mathrm{~nm} \mathrm{Ca} / 80 \mathrm{~nm} \mathrm{Ag}$ was deposited atop the PS1 layer in a vacuum chamber $\left(\approx 10^{-5}\right.$ Torr $)$. The current density-voltage $(J-V)$ characterization of the devices were carried out by using a Keithley 2400 source measurement. The thickness of PS1 is $50 \mathrm{~nm}$, which was measured by using a KLATencor P6 surface profilometer.

The $\mu_{\mathrm{e}} / \mu_{\mathrm{h}}$ value is calculated from Mott-Gurney equation (1):

$$
J_{S C L C}=\frac{9}{8} \varepsilon_{0} \varepsilon_{r} \mu_{\mathrm{cih}}\left(\frac{V^{2}}{L^{3}}\right)
$$

where $\mathrm{J}_{\mathrm{SCLC}}$ stands for current density, $\mathrm{V}$ is the applied potential, $\mathrm{L}$ is the thickness of the PS1 $(50 \mathrm{~nm}), \varepsilon_{\mathrm{r}}$ is the relative dielectric constant of the blend (3), $\varepsilon_{0}$ is the permittivity of free space $\left(8.85 \times 10^{-12} \mathrm{C} \mathrm{V}^{-1} \mathrm{~s}^{-1}\right)$. 


\section{Computational studies}

(1) DFT Computational details: All density function theory calculation were performed using Gaussion 09 software. $^{\mathrm{S} 3}$ (a) For 8 and the oligomers of PS1, D3B3LYP/6-31G $(\mathrm{d}, \mathrm{p})$ theoretical level with long-range correction with DFT-D3 ${ }^{\mathrm{S} 4}$ was used to optimize the structures and further validated by frequency analysis. Based on the relaxed structure, D3-B3LYP/Def2-TZVP computational level was used to identify the energy level of frontier orbitals. Polarizable continuum model (PCM) ${ }^{\mathrm{S} 5}$ method was used to treat solvent effect. UV spectra was simulated by using timedependent DFT with theoretical level of D3-B3LYP/6-31G(d, p). Raman spectra were also calculated with theoretical level of D3-B3LYP/6-31G(d, p). (b) For the trimer, as one representative unit of PS1, the initial structure was relaxed by using D3-BLYP/6-31G(d, p), and potential energy surface was calculated using modredundant optimization by the restriction of two twist angles at theoretical level of D3-BLYP/6-31G(d, p).

(2) Molecular Dynamic Calculations: UFFMD calculations: Molecular dynamic calculations were performed in Forcite module in Material Studio. ${ }^{\text {S6-S8 }}$ In flexible simulations, Universal force field (UFF) ${ }^{\mathrm{S} 9}$ was used for bond stretching, angle bending, and dihedral torsions as implemented in software. Atomic charges were estimated by QEq method. The long range van der Waals distance was set to 15.5 Å. Geometry optimization steps were firstly performed for initial structures until the following convergence criteria reached: $10^{-4} \mathrm{kcal} \mathrm{mol}^{-1}$ for energy, $5 \times 10^{-3} \mathrm{kcal}$ $\mathrm{mol}^{-1} \AA^{-1}$ for forces, and $5 \times 10^{-5} \AA$ for displacement. MD simulations within the NVT ensemble were carried out with a step size of $0.5 \mathrm{fs}$ up to a total of $200 \mathrm{ps}$ at $300 \mathrm{~K}$ and $500 \mathrm{~K}$. The Nose-Hoover thermostat was used to deal with temperature constant. AIBOMD calculations: Ab-initio Molecular Dynamics ( AIMD ) following Born-Oppenheimer strategy were performed using in CP2K 6.1 software. S10 Molecular dynamics calculations were conducted without any constraints in NVT ensemble. Kohn-shame DFT as implemented in Quickstep modules, utilizing mixed Gaussian and plane waves approach, was used as electronic structure 
computational method with exchange-correlation functional of PBE. And an energy cutoff of $450 \mathrm{Ry}$ is employed for the auxiliary plane wave expansion of the charge density. Valence electrons were treated by molecularly optimized Gaussian basis sets of double $\zeta$ plus polarization quality (MOLOPT-DZVP), ${ }^{11}$ and inner cores were described by norm conserving GTH-pseudopotentials. ${ }^{\text {S12 }}$ van der Waals interactions for $\pi-\pi$ stacking interaction were corrected by DFT-D3. ${ }^{\text {S4 }}$ To improve efficiency, the orbital transformation minimizer ${ }^{\mathrm{S} 13}$ was used to promote the convergence of SCF. The equations of motion were integrated with a time step of $0.5 \mathrm{fs}$ and the temperature maintained at $300 \mathrm{~K}$ and $500 \mathrm{~K}$ using the Nose-Hoover thermostat. ${ }^{\mathrm{S} 14} \mathrm{MD}$ calculations were run for $20.0 \mathrm{ps}$ to ensure they were equilibrated. 


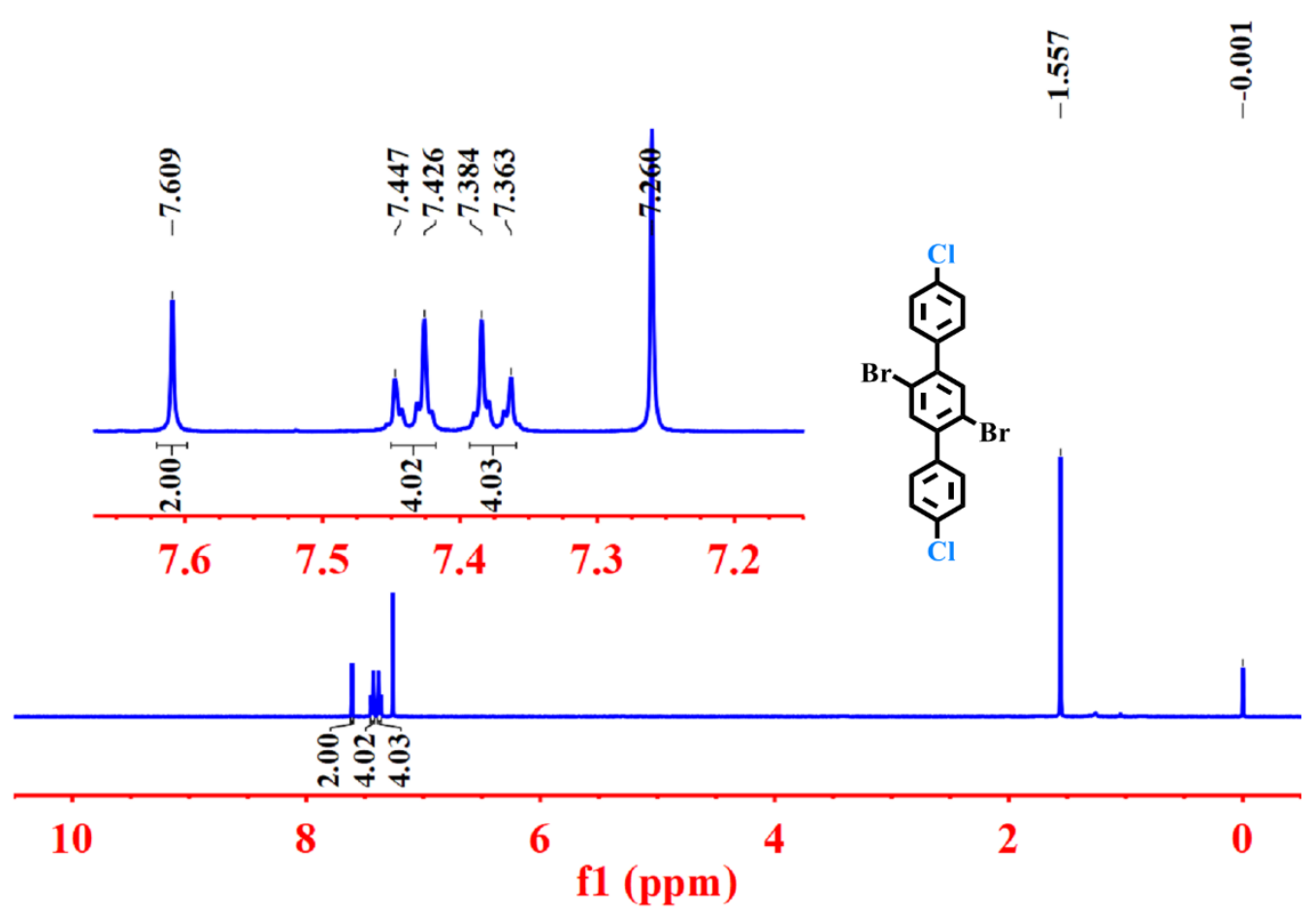

Figure S1. ${ }^{1} \mathrm{H}$ NMR spectrum of compound 4 in $\mathrm{CDCl}_{3}$. 


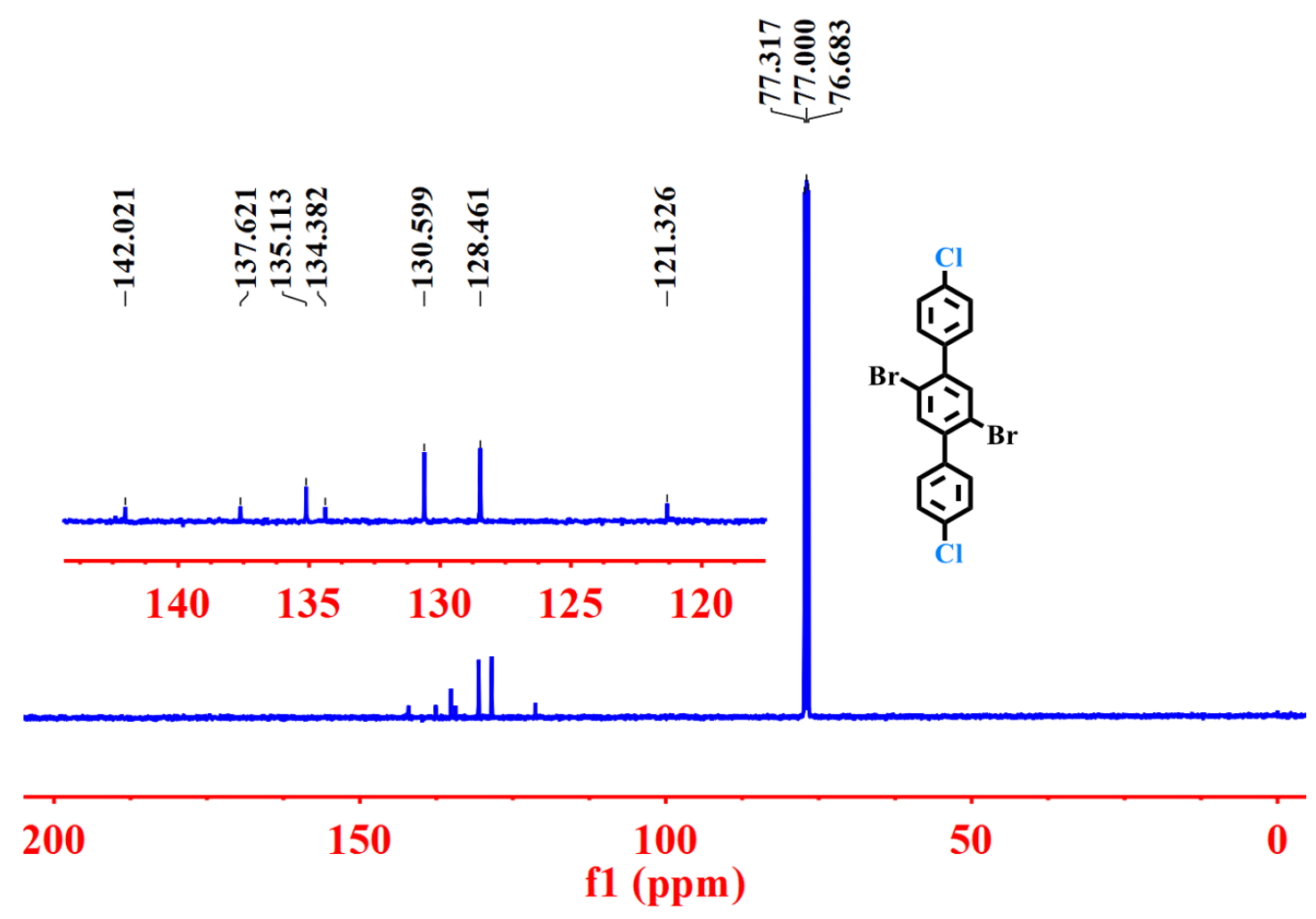

Figure S2. ${ }^{13} \mathrm{C}$ NMR spectrum of compound 4 in $\mathrm{CDCl}_{3}$. 


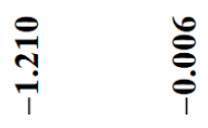

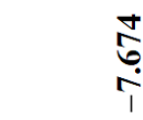

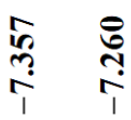
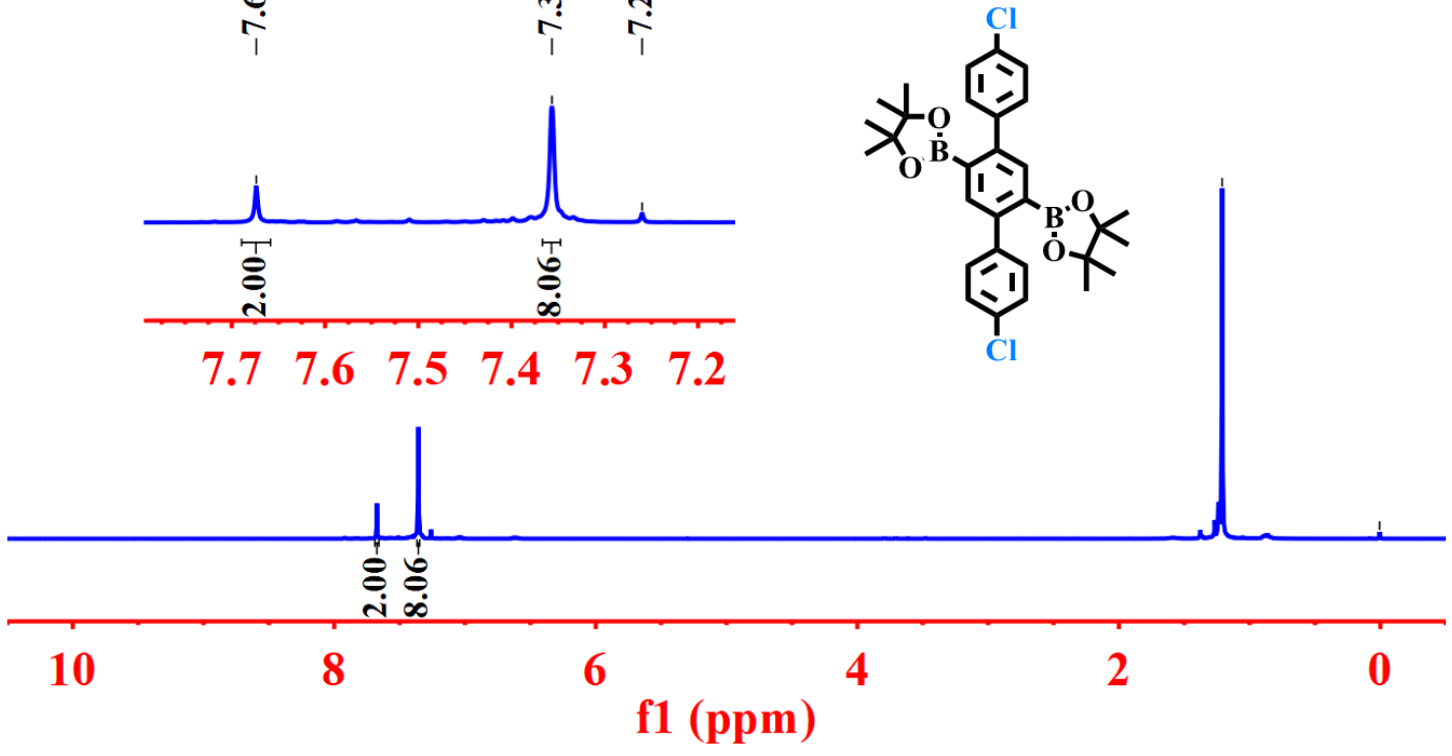

Figure S3. ${ }^{1} \mathrm{H}$ NMR spectrum of compound 5 in $\mathrm{CDCl}_{3}$. 


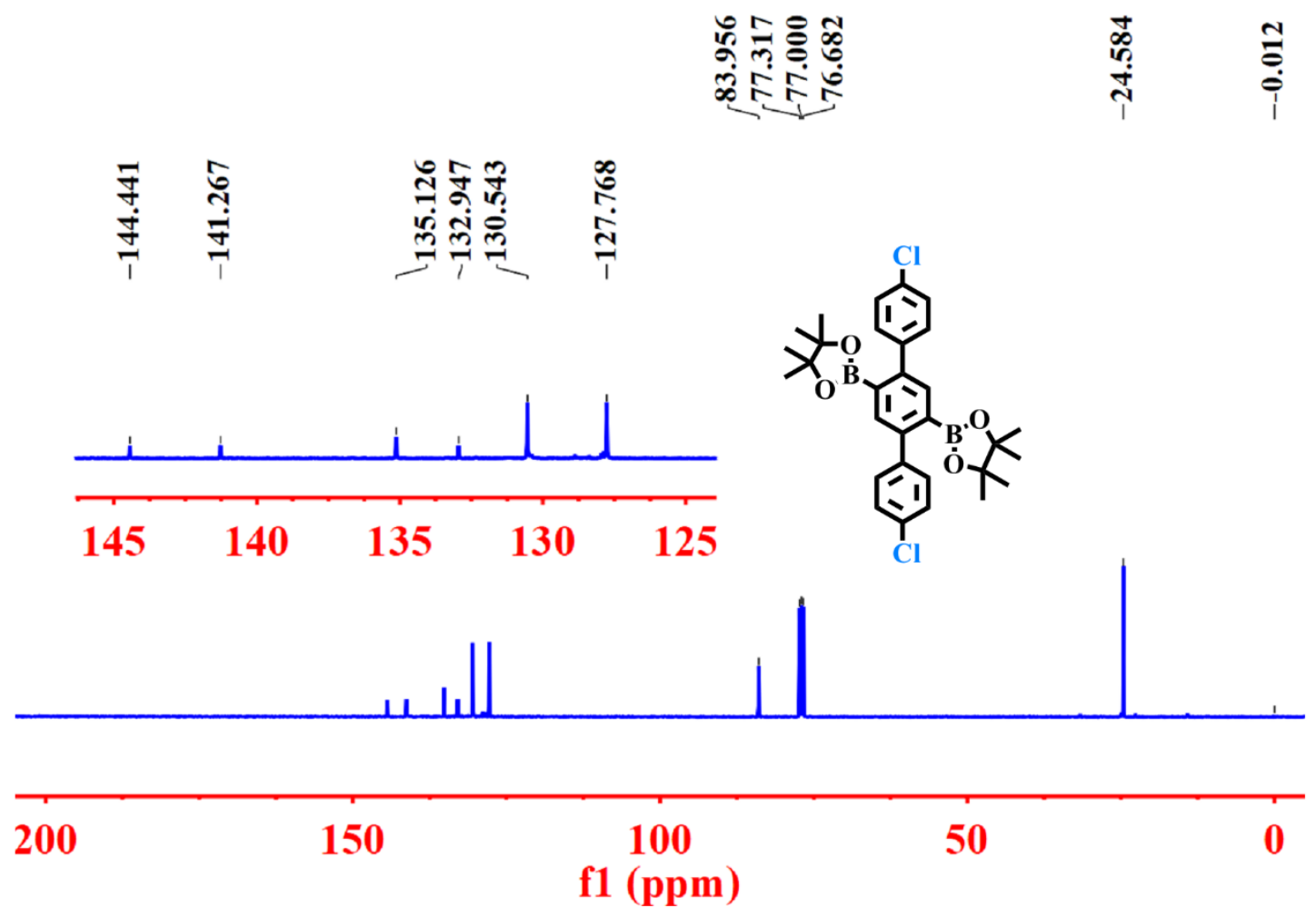

Figure S4. ${ }^{13} \mathrm{C}$ NMR spectrum of compound 5 in $\mathrm{CDCl}_{3}$.

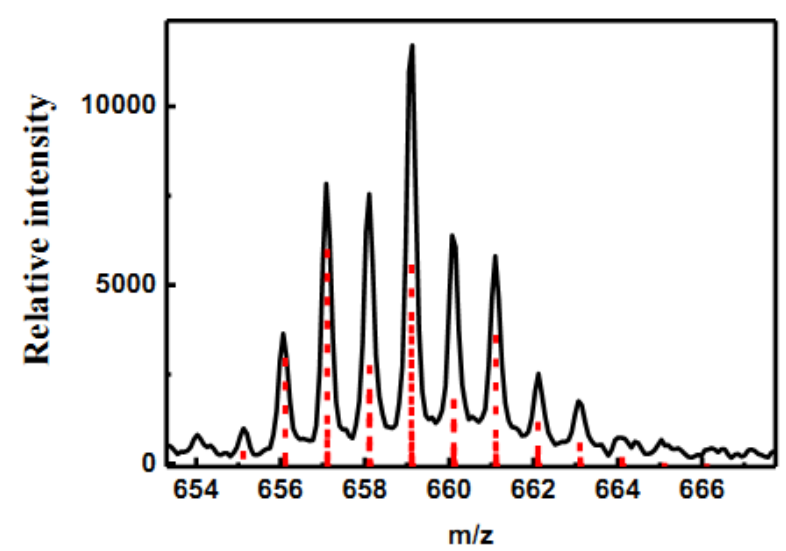

Figure S5. MALDI-TOF-MS spectrum (black) and simulated data (red) for compound 5. 


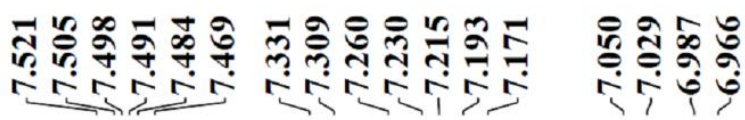

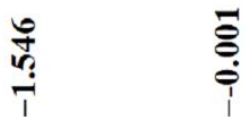
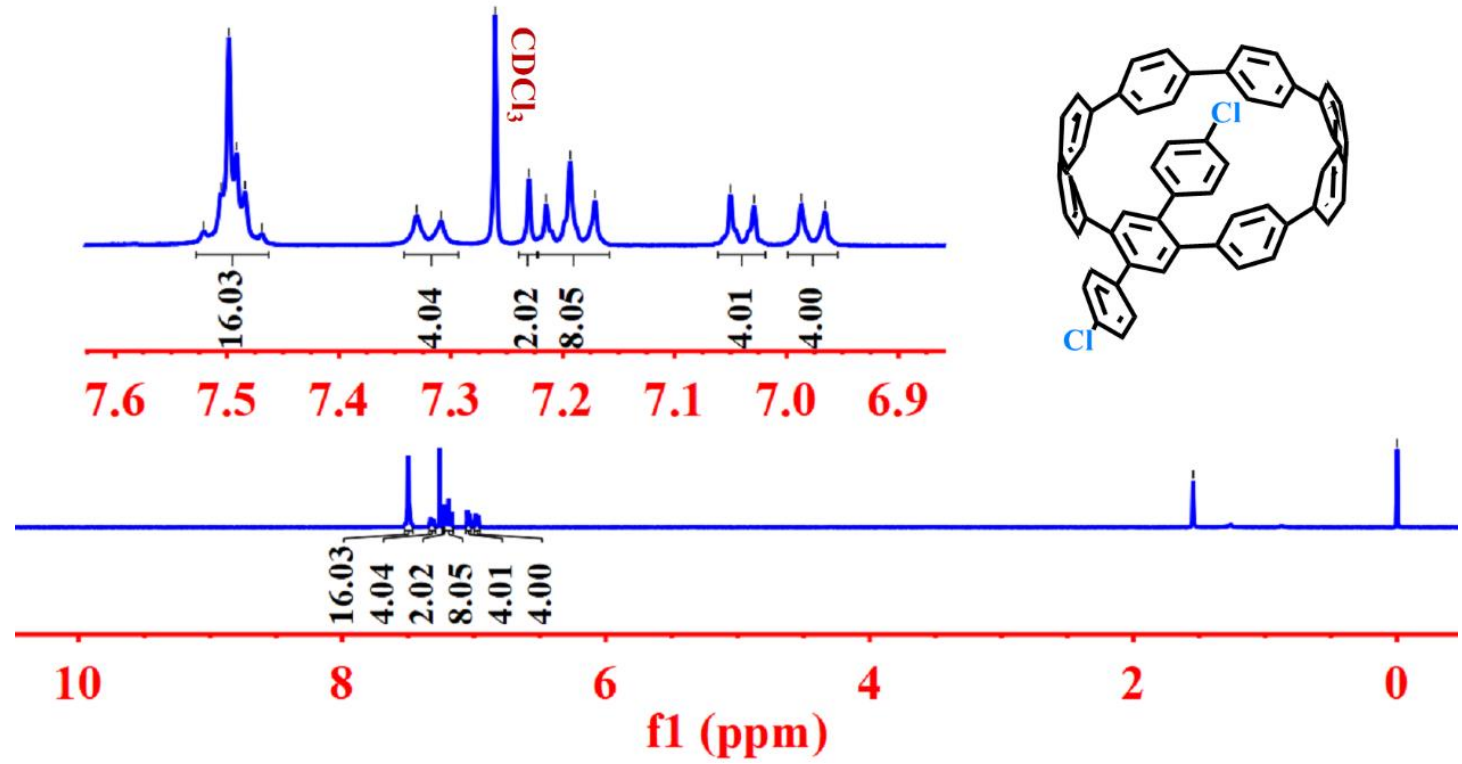

Figure S6. ${ }^{1} \mathrm{H}$ NMR spectrum of compound $\mathbf{8}$ in $\mathrm{CDCl} 3$. 


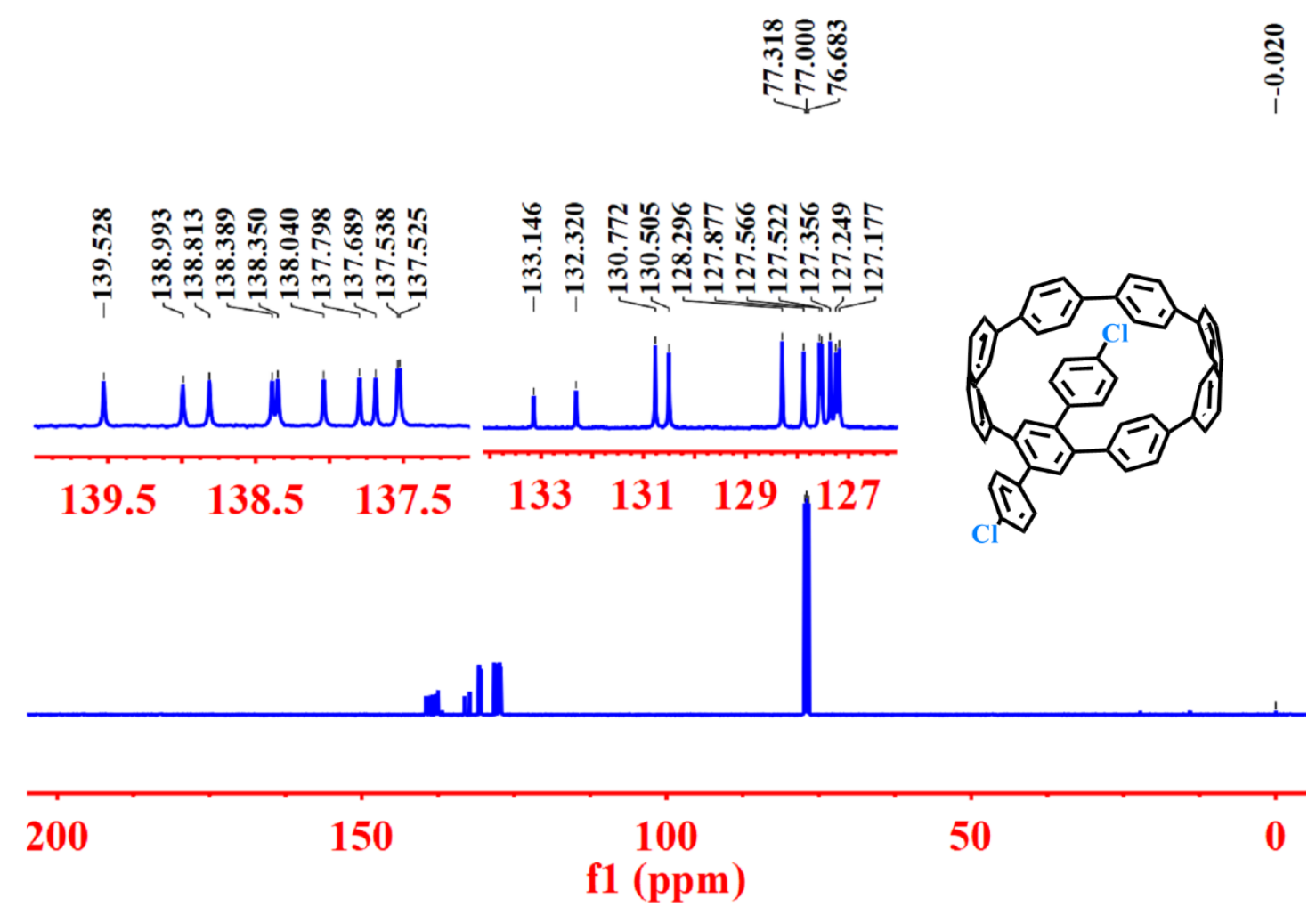

Figure S7. ${ }^{13} \mathrm{C}$ NMR spectrum of compound $\mathbf{8}$ in $\mathrm{CDCl}_{3}$. 


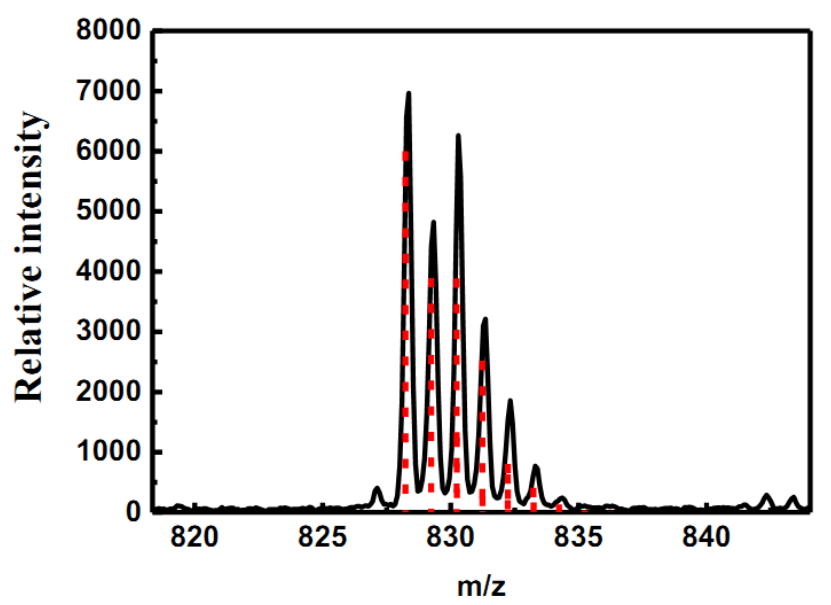

Figure S8. MALDI-TOF-MS spectrum (black) and simulated data (red) for compound 8.

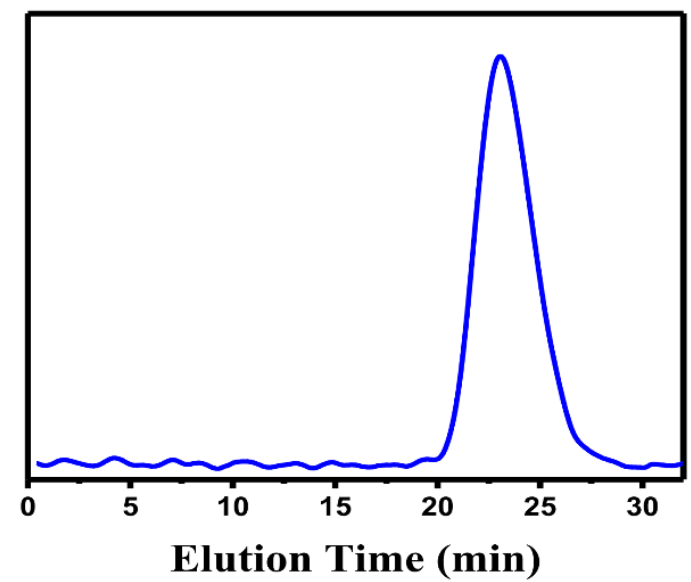

Figure S9. GPC trace of PS1 using DMF as the solvent. 


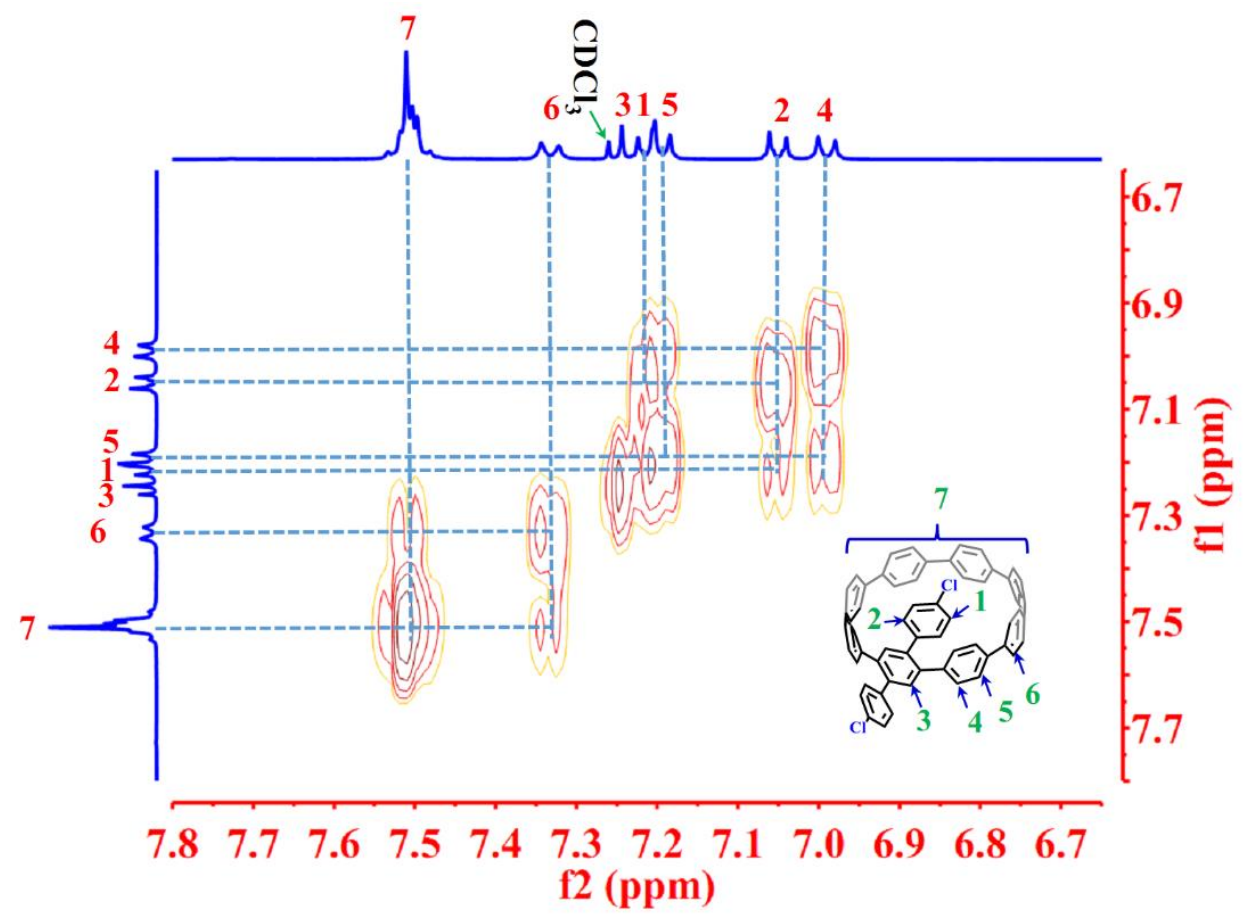

Figure S10. Expanded 2D ${ }^{1} \mathrm{H}_{-}{ }^{1} \mathrm{H}$ COSY NMR spectrum $\left(400 \mathrm{MHz}, \mathrm{CDCl}_{3}\right)$ of compound $\mathbf{8}$. 


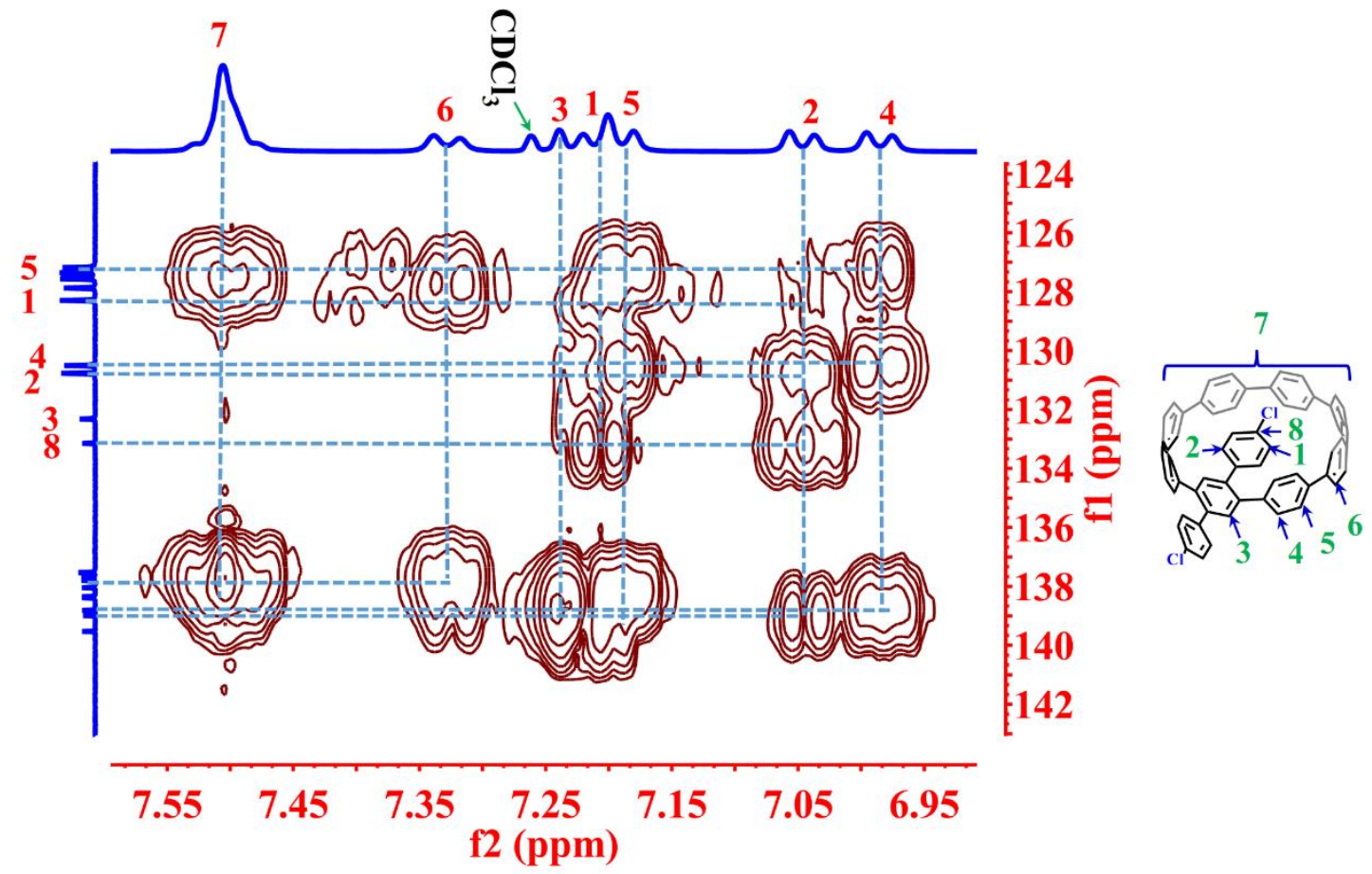

Figure S11. Expanded 2D ( $\mathrm{H}, \mathrm{C})-\mathrm{HMBC} \mathrm{NMR}$ spectrum $\left(400 \mathrm{MHz}, \mathrm{CDCl}_{3}\right)$ of compound $\mathbf{8}$. 


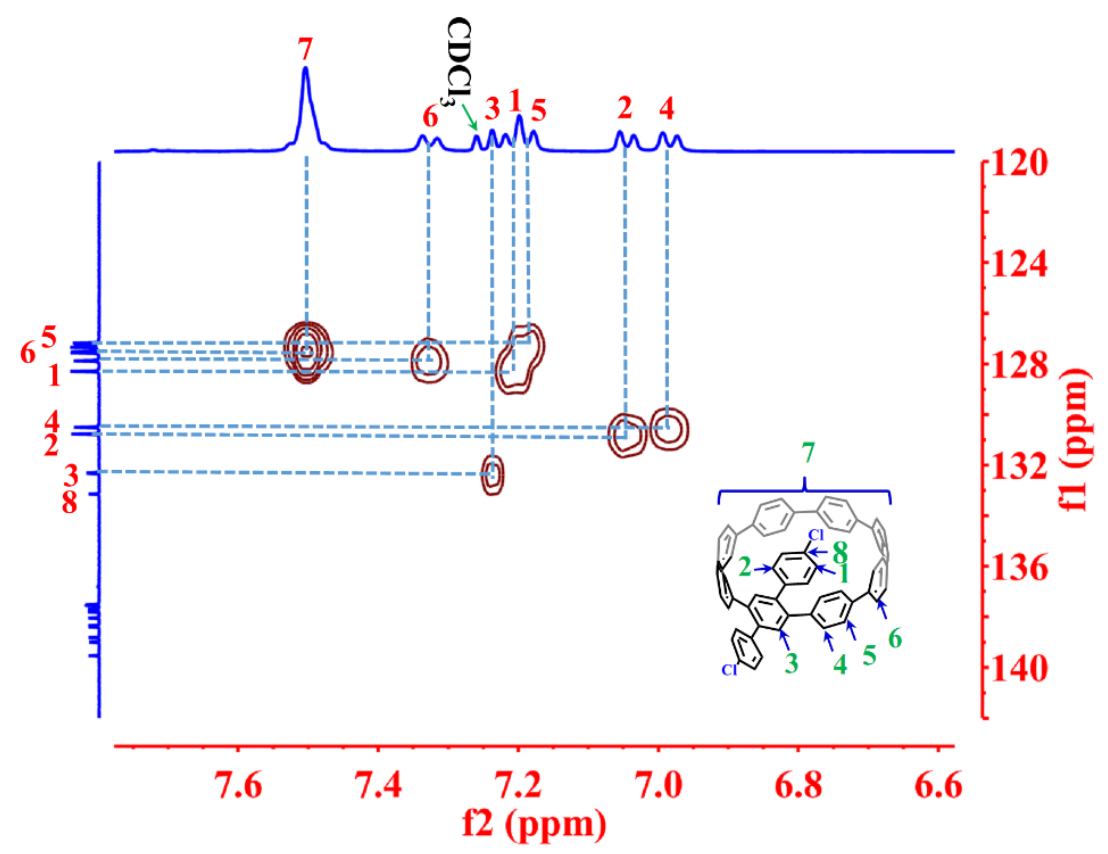

Figure S12. Expanded 2D ( $\mathrm{H}, \mathrm{C})$-HSQC NMR spectrum $\left(400 \mathrm{MHz}, \mathrm{CDCl}_{3}\right)$ of compound $\mathbf{8}$. 


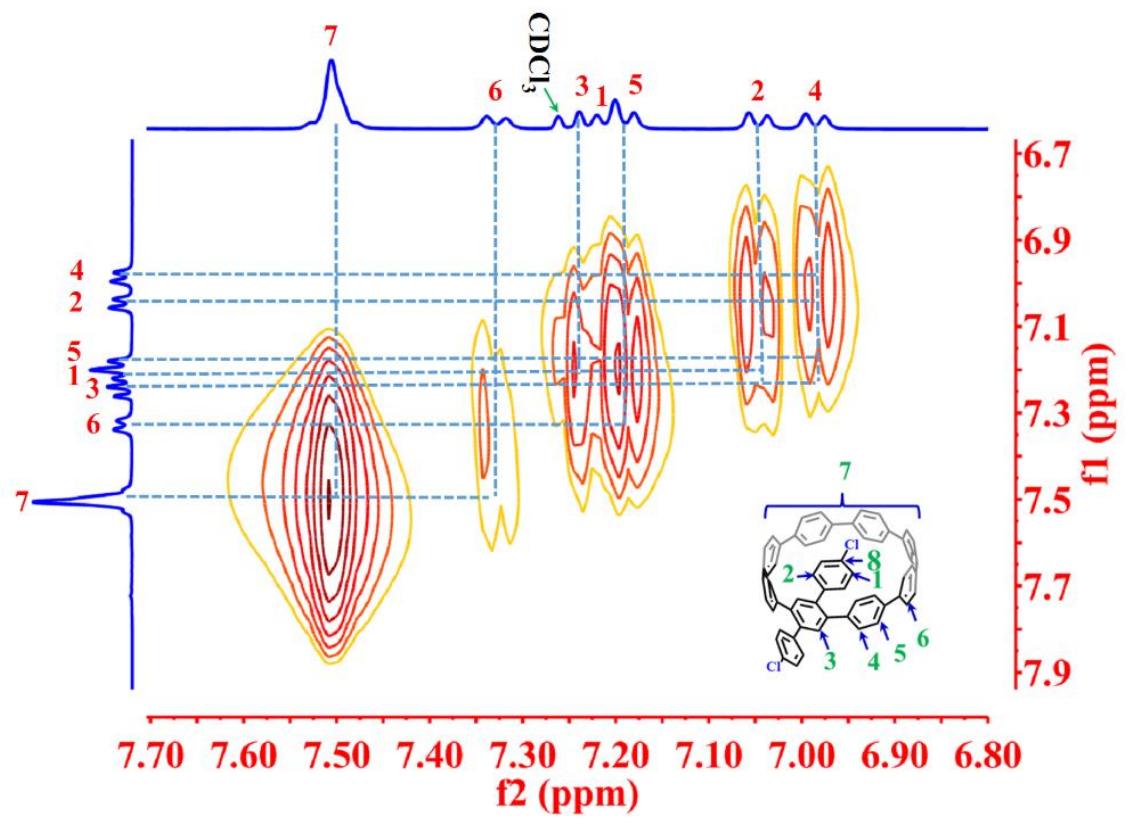

Figure S13. Expanded 2D (H, H)-ROESY NMR spectrum (400 MHz, $\left.\mathrm{CDCl}_{3}\right)$ of compound 8. 


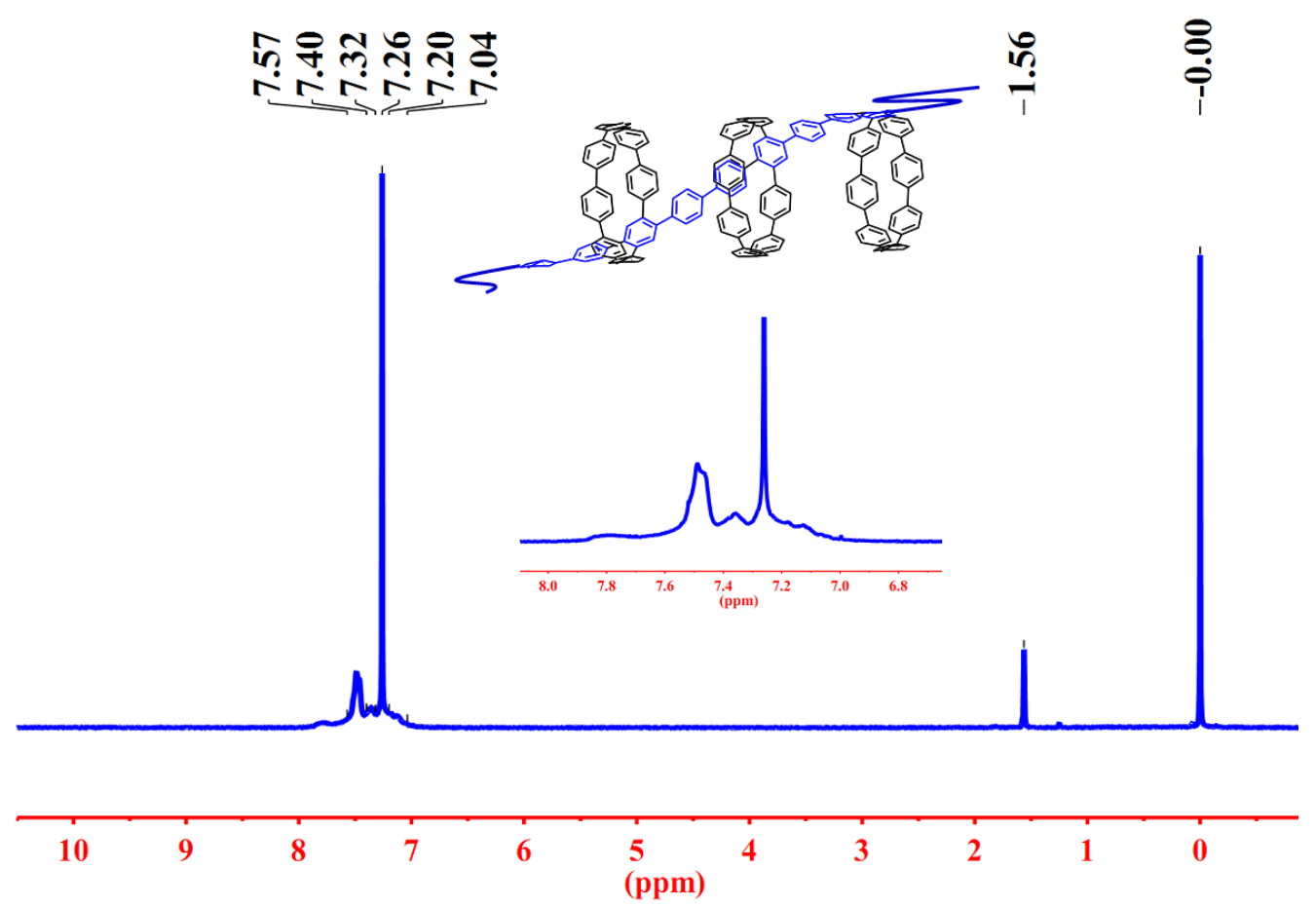

Figure S14. ${ }^{1} \mathrm{H}$ NMR spectrum of PS1 in $\mathrm{CDCl}_{3}$. 
(a)
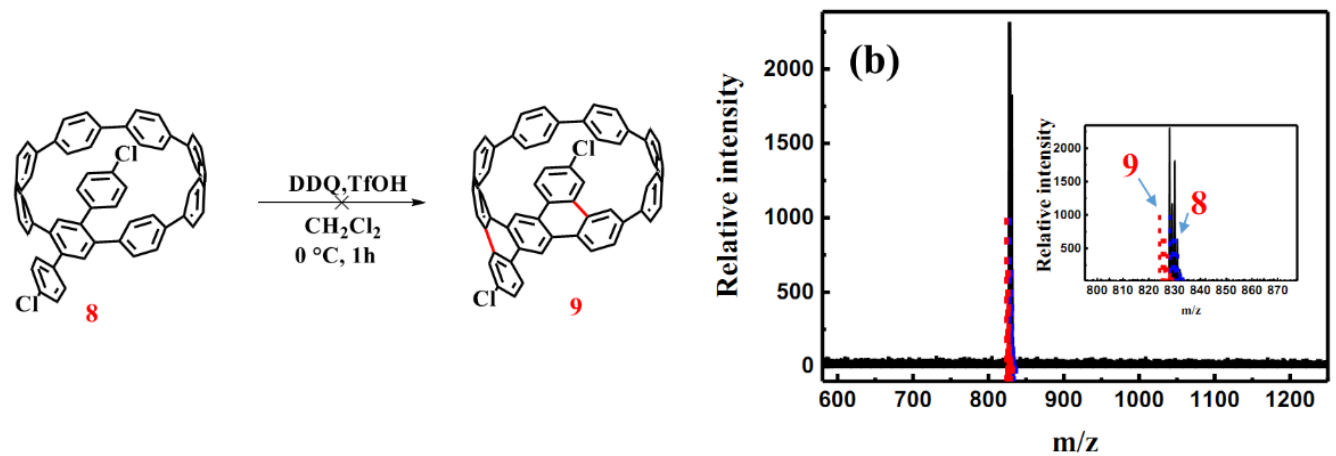

Figure S15. (a) The Scholl reaction for compound 8. (b) MALDI-TOF-MS spectrum of compound $\mathbf{8}$ after Scholl oxidation (black), simulated data (blue) for compound $\mathbf{8}$, simulated data (red) for compound 9.

(a)
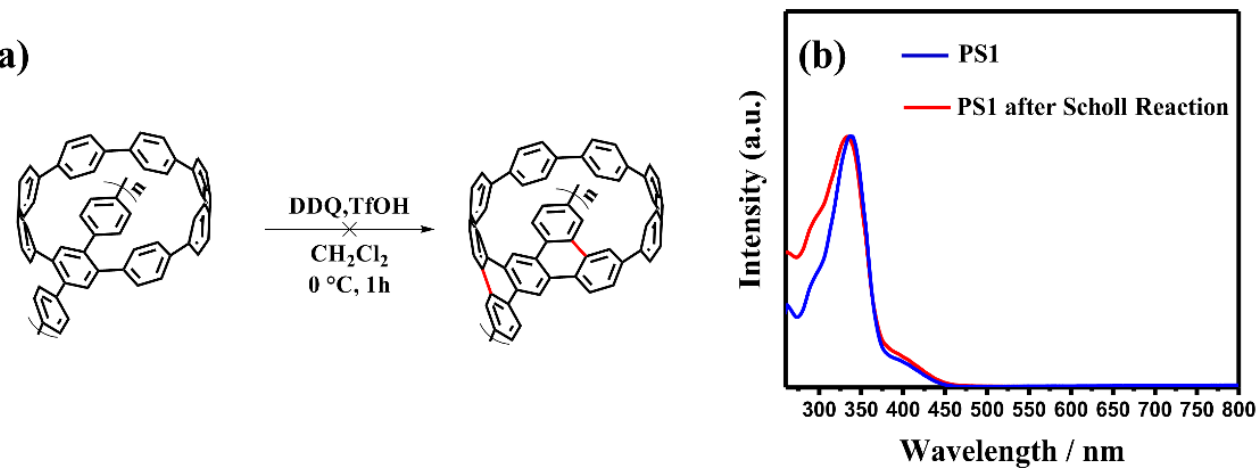

Figure S16. (a) Scholl oxidation on PS1. (b) UV-vis absorption spectra of PS1 (blue) and PS1 after Scholl oxidation (red) in $\mathrm{CH}_{2} \mathrm{Cl}_{2}$. 
(a)

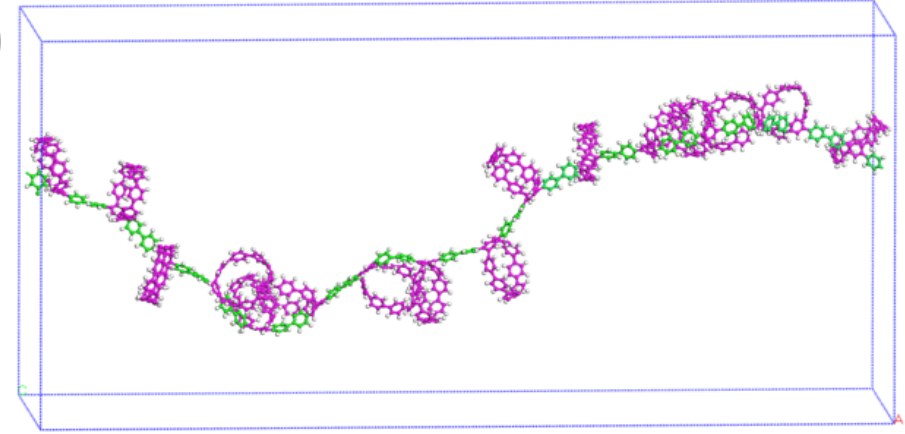

(b)

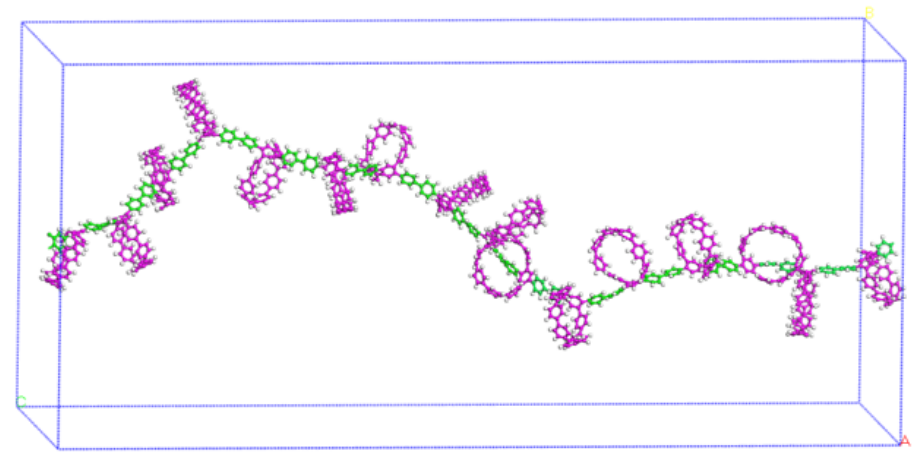

Figure S17. Periodic structures of PS1 after 200 ps UFFMD simulation at $300 \mathrm{~K}$ (a) and $500 \mathrm{~K}(\mathrm{~b})$. 

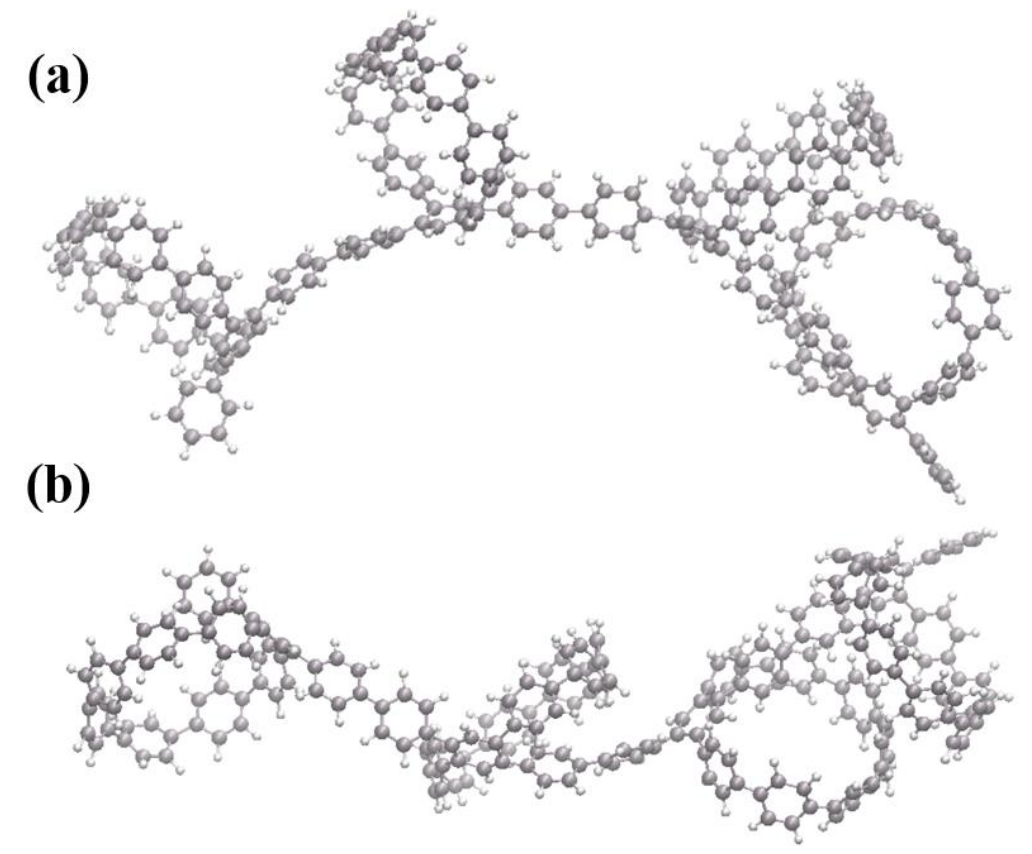

Figure S18. Tetramer structure of PS1 after 20 ps AIMD simulation at $300 \mathrm{~K}(\mathrm{a})$ and $500 \mathrm{~K}(\mathrm{~b})$.

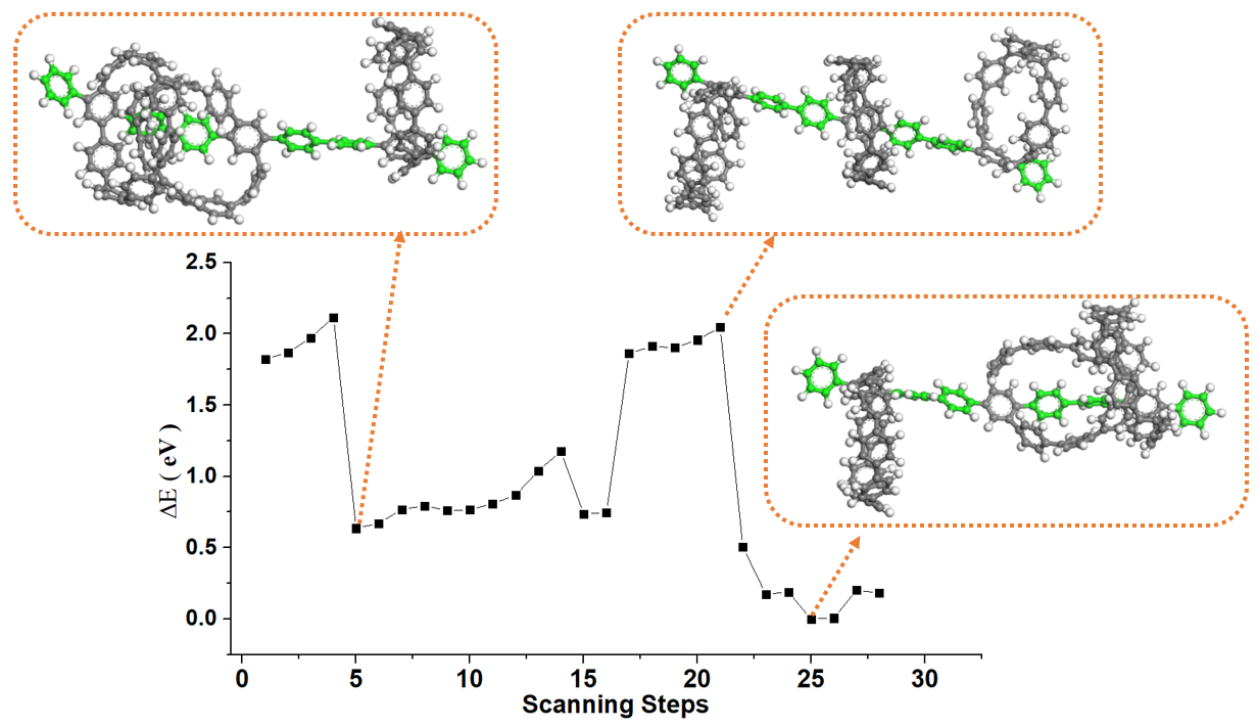

Figure S19. Potential energy surface of the trimer by using BLYP/6-31G(d, p): [8]cyclo-para-phenylene moieties stacking configuration (left and right) and parallelmode configurations (middle). 


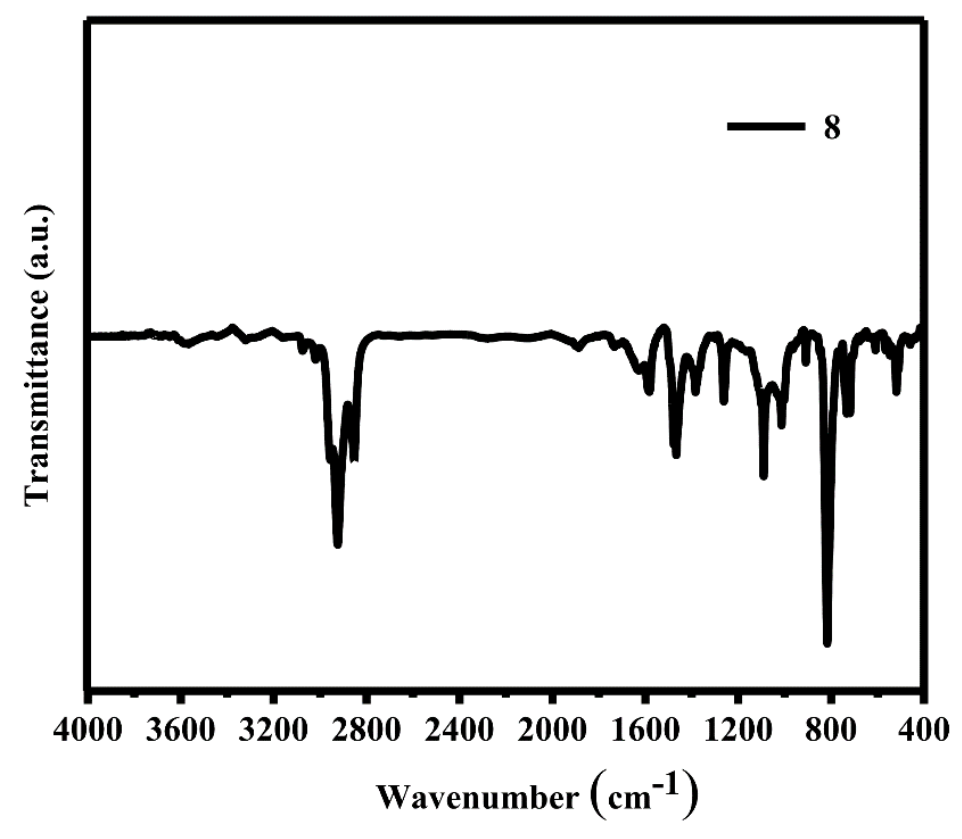

Figure S20. FTIR spectra of compound 8 .

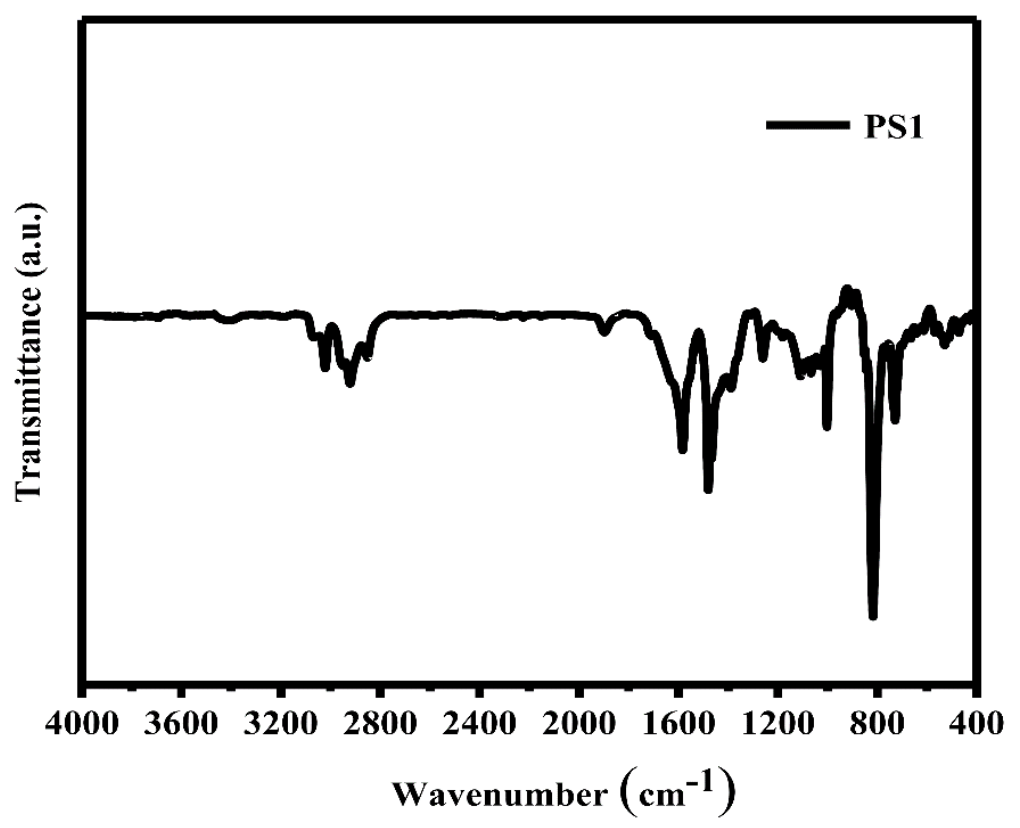

Figure S21. FTIR spectrum of PS1. 


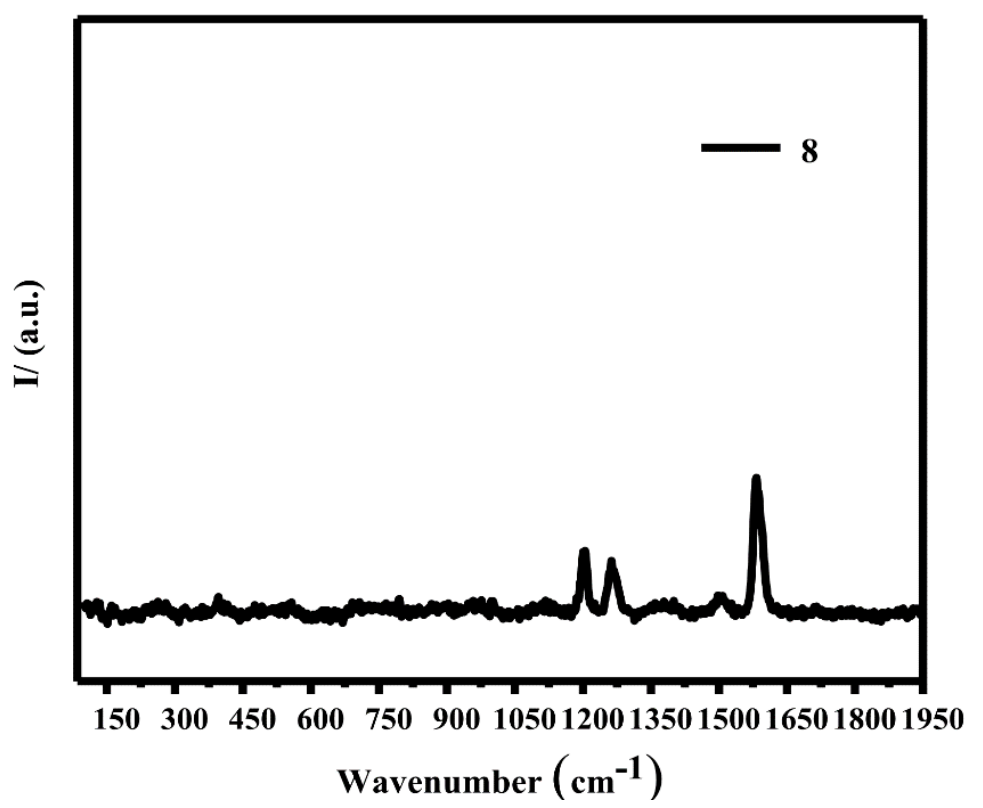

Figure S22. Raman spectra (excited at $633 \mathrm{~nm}$ ) of compound 8.

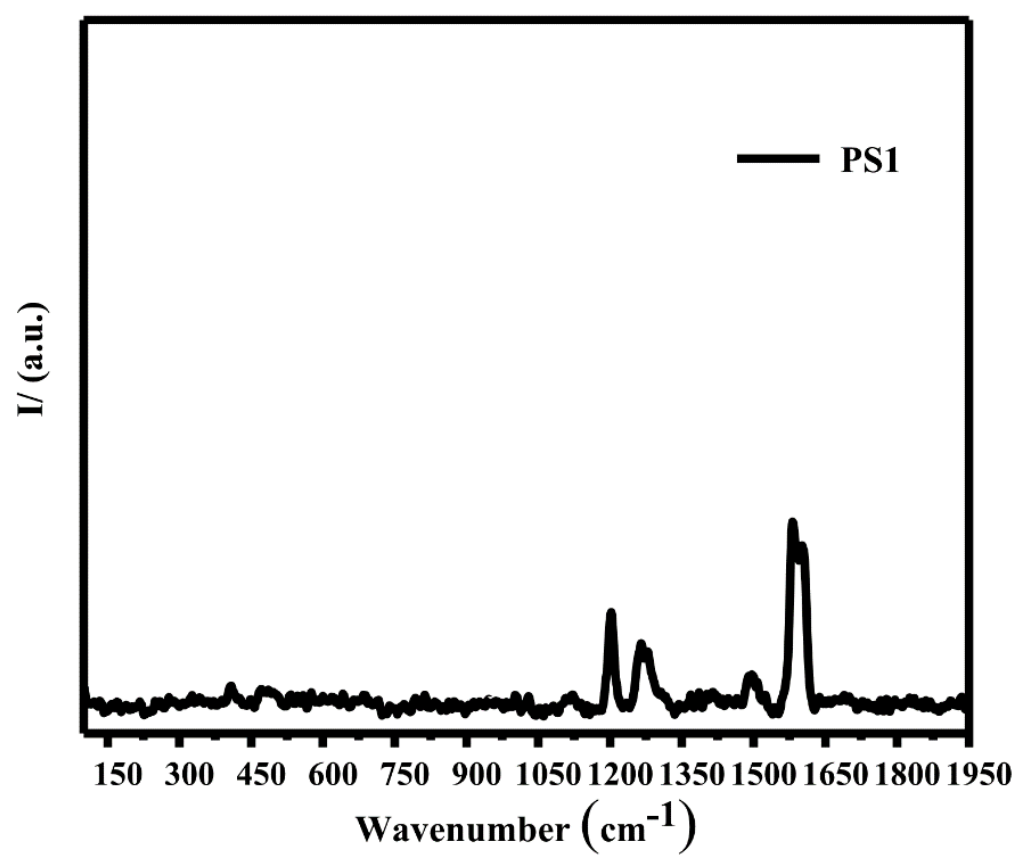

Figure S23. Raman spectra (excited at $633 \mathrm{~nm}$ ) of PS1. 


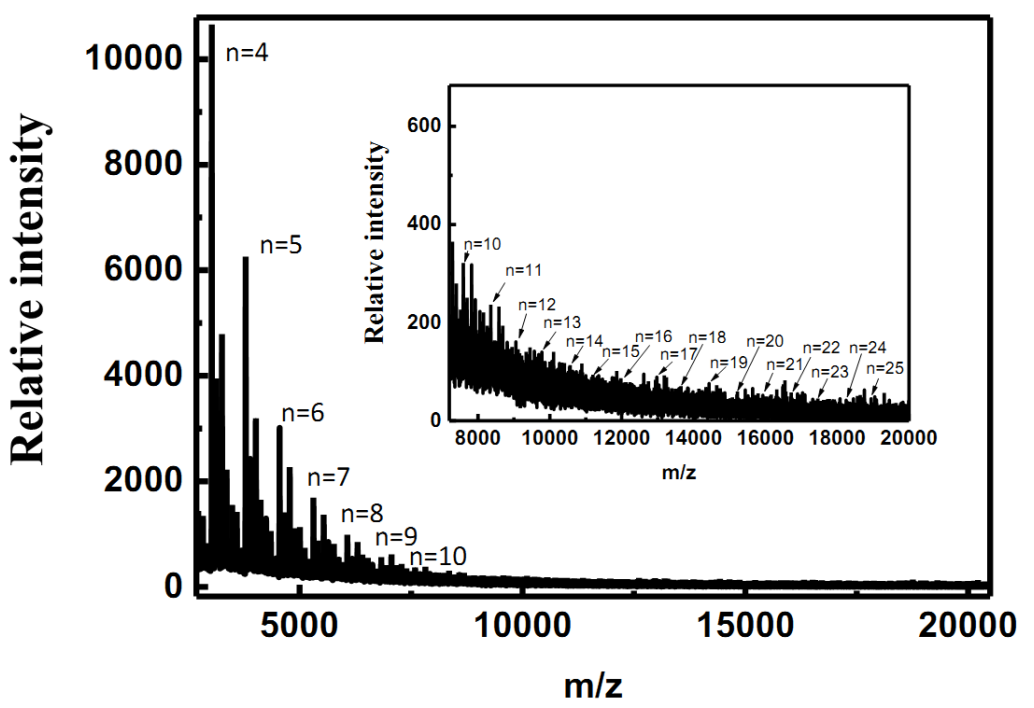

Figure 24. MALDI-TOF-MS spectrum for PS1. 

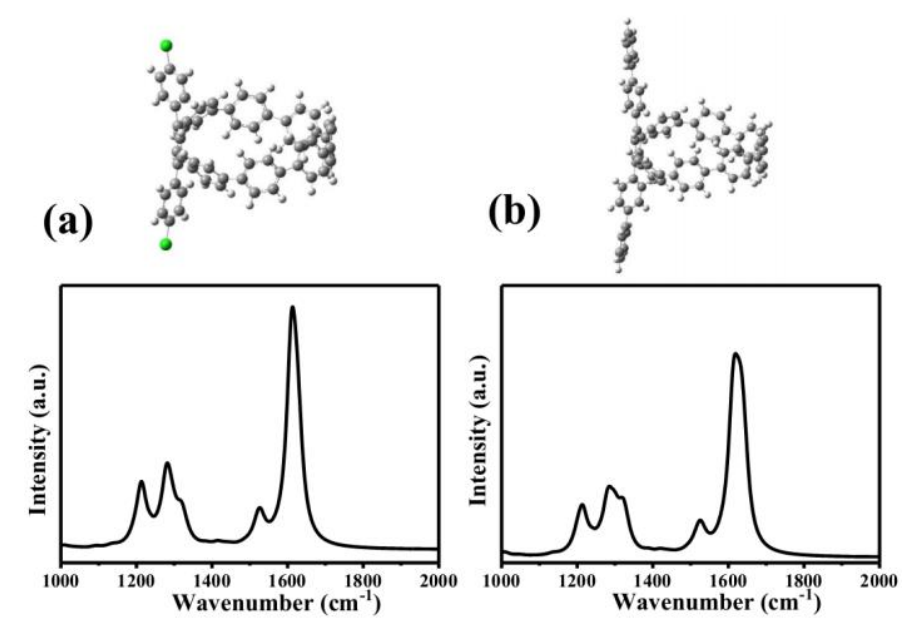

Figure S25. DFT simulated Raman spectra of 8 (a) and the repeating unit of PS1 (b). 


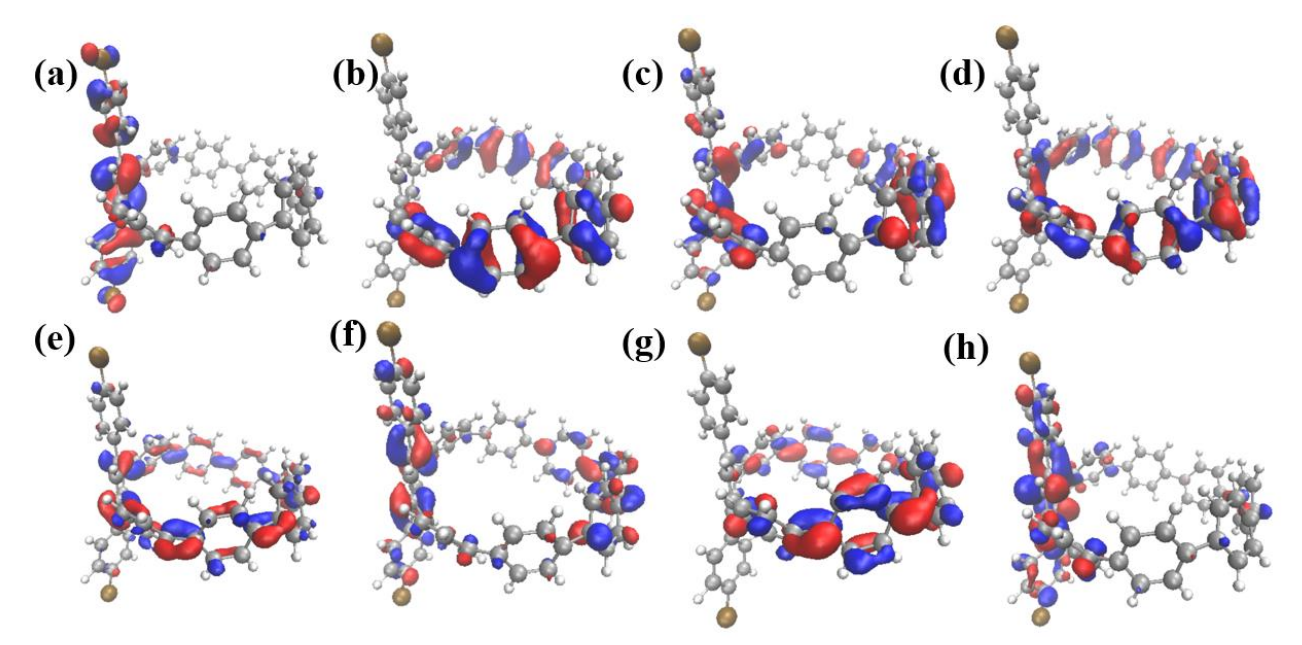

Figure S26. Frontier orbital of 8: HOMO-3(a), HOMO-2(b), HOMO-1(c), HOMO(d), LUMO(e), LUMO+1(f), LUMO+2(g) and LUMO+3(h).

(a)

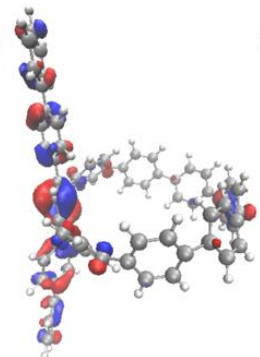

(e)

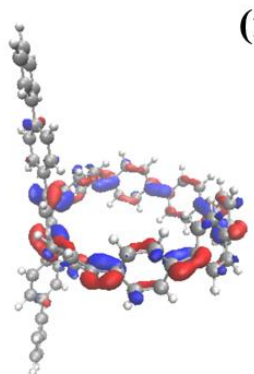

(b)

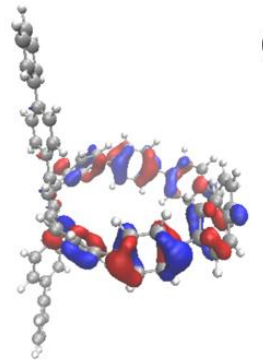

(f)

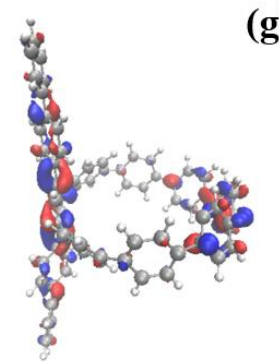

(c)

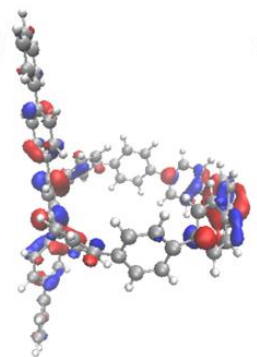

(g)

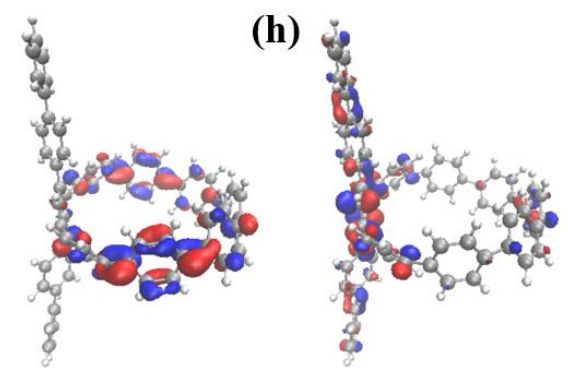

Figure S27. Frontier orbital of monomer of PS1: HOMO-3(a), HOMO-2(b), HOMO1(c), HOMO(d), LUMO(e), LUMO+1(f), LUMO+2(g) and LUMO+3(h). 

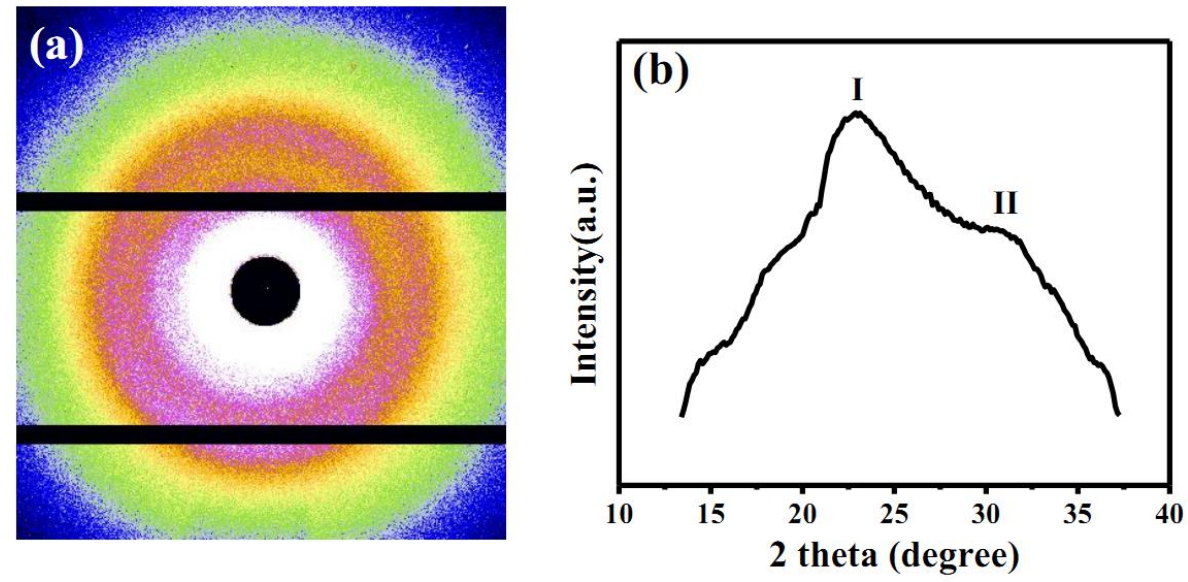

Figure S28. (a) Selected 2D WAXD pattern of PS1 at room temperature. (b) Corresponding 1D WAXD intensity curve of PS1 sample. 


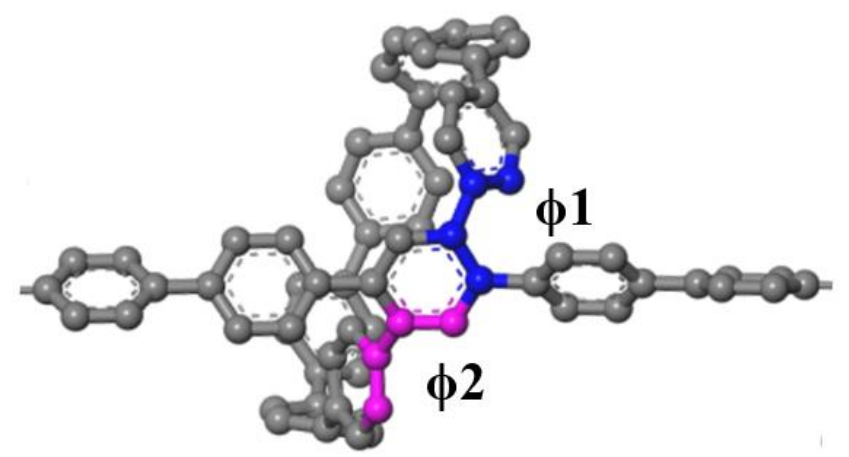

Figure S29. Two twist angles of trimer for PES calculation.

Table S1. Orbital energy level of compounds.

\begin{tabular}{ccc}
\hline Configuration & $\mathbf{8}$ & oligomer of PS1 \\
\hline $\mathbf{E}_{\text {LUMO+3 }}$ & -1.369 & -1.348 \\
$\mathbf{E}_{\text {LUMO+2 }}$ & -1.676 & -1.582 \\
$\mathbf{E}_{\text {LUMO+1 }}$ & -1.850 & -1.792 \\
$\mathbf{E}_{\text {LUMO }}$ & -2.326 & -2.219 \\
$\mathbf{E}_{\text {HOMO }}$ & -5.377 & -5.284 \\
$\mathbf{E}_{\text {HOMO-1 }}$ & -5.919 & -5.763 \\
$\mathbf{E}_{\text {HOMO-2 }}$ & -5.949 & -5.844 \\
$\mathbf{E}_{\text {HOMO-3 }}$ & -6.406 & -6.136 \\
$\Delta \mathbf{E}_{\text {HOMO-LUMO }}$ & 3.051 & 3.060 \\
\hline
\end{tabular}

Table S2. Main transitions of 8 and oligomer of PS1 with oscillator strength $(f)$ more than 0.10 .

\begin{tabular}{|c|c|c|c|}
\hline$\lambda_{\exp } / \mathrm{nm}$ & $\lambda_{\mathrm{DFT}} / \mathrm{nm}$ & main transitions (coefficient) & $f$ \\
\hline \multicolumn{4}{|c|}{ Compound 8} \\
\hline \multirow{4}{*}{388} & 384.41 & HOMO $\rightarrow$ LUMO+1 (69\%) & 0.4373 \\
\hline & 374.88 & HOMO-2 $\rightarrow$ LUMO (70\%) & 0.8196 \\
\hline & 373.59 & HOMO-1 $\rightarrow$ LUMO $\quad(71.0 \%)$ & 0.5090 \\
\hline & 361.23 & $\mathrm{HOMO} \rightarrow \mathrm{LUMO}+2(70 \%)$ & 0.8033 \\
\hline 340 & 327.48 & $\begin{array}{l}\text { HOMO-3 } \rightarrow \text { LUMO } \quad(55.1 \%) \\
\text { HOMO-1 } \rightarrow \text { LUMO }(-17.4 \%) \\
\text { HOMO } \rightarrow \text { LUMO +3 }(38.7 \%)\end{array}$ & 0.8350 \\
\hline \multicolumn{4}{|c|}{ Oligomer of PS1 } \\
\hline \multirow{3}{*}{381} & 375.44 & $\begin{array}{l}\text { HOMO-1 } \rightarrow \text { LUMO }(67.7 \%) \\
\text { HOMO } \rightarrow \text { LUMO+1 }(15.9 \%)\end{array}$ & 0.4443 \\
\hline & 371.80 & $\begin{array}{c}\text { HOMO-2 } \rightarrow \text { LUMO }(68.9 \%) \\
\text { HOMO } \rightarrow \text { LUMO+2 }(-10.9 \%)\end{array}$ & 0.4256 \\
\hline & 358.05 & $\mathrm{HOMO} \rightarrow \mathrm{LUMO}+2(68.4 \%)$ & 0.8272 \\
\hline 335 & 333.23 & $\begin{array}{c}\text { HOMO-3 } \rightarrow \text { LUMO }(40.2 \%) \\
\text { HOMO- } \rightarrow \text { LUMO+1 }(27.2 \%) \\
\text { HOMO } \rightarrow \text { LUMO+3 }(49.3 \%)\end{array}$ & 1.3111 \\
\hline
\end{tabular}


Table S3. Relaxed structures of 8 and oligomer of PS1.

\begin{tabular}{|c|c|c|c|c|c|c|c|}
\hline \multicolumn{8}{|c|}{ Compound 8} \\
\hline $\mathbf{C}$ & -3.834414 & -2.488866 & -4.522767 & $\mathrm{C}$ & 6.378717 & -2.285436 & 1.570572 \\
\hline $\mathrm{C}$ & -4.643715 & -3.607637 & -4.341144 & $\mathrm{C}$ & 5.499499 & -1.972629 & 2.623213 \\
\hline C & -5.249839 & -3.870549 & -3.113882 & $\mathrm{C}$ & 6.995059 & -1.167207 & 0.814524 \\
\hline C & -3.631096 & -1.620977 & -3.452132 & $\mathrm{C}$ & 7.139710 & 0.113539 & 1.380127 \\
\hline C & 5.501042 & 1.970206 & -2.623144 & $\mathrm{C}$ & -5.033546 & 2.996359 & 2.055165 \\
\hline C & 7.140373 & -0.116437 & -1.379625 & $\mathrm{C}$ & -5.246838 & 3.873334 & 3.114015 \\
\hline $\mathbf{C}$ & 4.512928 & 2.856566 & -3.025556 & $\mathrm{C}$ & -4.223713 & 1.858466 & 2.202383 \\
\hline $\mathbf{C}$ & 2.068235 & 4.429378 & -3.432264 & $\mathrm{C}$ & -3.630034 & 1.622372 & 3.452284 \\
\hline C & -2.180352 & 4.130124 & -2.289537 & $\mathrm{C}$ & -4.641305 & 3.609668 & 4.341410 \\
\hline C & 0.702491 & 4.507007 & -3.180031 & $\mathrm{C}$ & -3.832766 & 2.490337 & 4.522970 \\
\hline C & -3.192093 & 3.267114 & -1.868251 & $\mathrm{H}$ & -3.362663 & -2.303937 & -5.480751 \\
\hline C & -4.225042 & -1.856527 & -2.202256 & $\mathrm{H}$ & -5.881658 & -4.742396 & -2.990971 \\
\hline C & -3.984793 & 0.447734 & -1.292998 & $\mathrm{H}$ & -2.976946 & -0.766184 & -3.586312 \\
\hline $\mathbf{C}$ & -5.035755 & -2.993792 & -2.055011 & $\mathrm{H}$ & 5.483996 & 0.966816 & -3.032187 \\
\hline C & -2.186471 & -3.148081 & -0.303639 & $\mathrm{H}$ & 7.147177 & -0.235234 & -2.458050 \\
\hline C & -4.036690 & -0.929983 & -1.061186 & $\mathrm{H}$ & 3.767807 & 2.506057 & -3.730208 \\
\hline C & -1.186764 & -4.010687 & 0.113089 & $\mathrm{H}$ & 2.400119 & 4.011912 & -4.377182 \\
\hline C & 1.152437 & -5.492282 & 1.041628 & $\mathrm{H}$ & -2.199393 & 4.503279 & -3.309031 \\
\hline C & 5.364870 & -4.503644 & 1.507739 & $\mathrm{H}$ & 0.011806 & 4.111387 & -3.917806 \\
\hline C & 2.517107 & -5.390009 & 1.282432 & $\mathrm{H}$ & -3.971508 & 2.993237 & -2.572788 \\
\hline C & 6.356992 & -3.613822 & 1.103364 & $\mathrm{H}$ & -3.958776 & 0.788694 & -2.322118 \\
\hline $\mathrm{C}$ & 7.123953 & -1.256444 & -0.584334 & $\mathrm{H}$ & -5.509220 & -3.188804 & -1.099182 \\
\hline C & 6.996037 & 1.164394 & -0.814114 & $\mathrm{H}$ & -2.126396 & -2.739440 & -1.303410 \\
\hline C & 6.380242 & 2.282777 & -1.570405 & $\mathrm{H}$ & -0.379961 & -4.231165 & -0.576224 \\
\hline C & 6.359226 & 3.611306 & -1.103565 & $\mathrm{H}$ & 0.817467 & -5.913785 & 0.099441 \\
\hline C & 7.124268 & 1.253563 & 0.584829 & $\mathrm{H}$ & 5.337412 & -5.492692 & 1.061250 \\
\hline C & 4.350060 & 4.104485 & -2.397506 & $\mathrm{H}$ & 3.205340 & -5.698943 & 0.503069 \\
\hline C & 5.367676 & 4.501572 & -1.508330 & $\mathrm{H}$ & 7.073139 & -3.935570 & 0.353709 \\
\hline C & 0.219475 & 4.925476 & -1.926817 & $\mathrm{H}$ & 7.076950 & -2.225332 & -1.070063 \\
\hline C & 3.009079 & 4.739733 & -2.432004 & $\mathrm{H}$ & 7.075540 & 3.932888 & -0.354003 \\
\hline C & 2.520194 & 5.389041 & -1.282882 & $\mathrm{H}$ & 7.077348 & 2.222457 & 1.070548 \\
\hline C & -1.100806 & 4.450861 & -1.446502 & $\mathrm{H}$ & 5.340634 & 5.490711 & -1.062015 \\
\hline C & -1.183949 & 4.010585 & -0.113270 & $\mathrm{H}$ & 3.208577 & 5.697729 & -0.503554 \\
\hline C & 1.155573 & 5.491689 & -1.041955 & $\mathrm{H}$ & -0.376817 & 4.230363 & 0.575880 \\
\hline C & -3.165141 & 2.679139 & -0.589389 & $\mathrm{H}$ & 0.820807 & 5.913300 & -0.099744 \\
\hline C & -2.184122 & 3.148556 & 0.303534 & $\mathrm{H}$ & -3.973373 & -2.991479 & 2.572887 \\
\hline C & -3.843822 & -1.391753 & 0.267469 & $\mathrm{H}$ & -3.959187 & -0.786910 & 2.322200 \\
\hline C & -3.842906 & 1.393482 & -0.267392 & $\mathrm{H}$ & -2.201906 & -4.502307 & 3.309106 \\
\hline C & -4.036018 & 0.931826 & 1.061283 & $\mathrm{H}$ & 0.009306 & -4.111546 & 3.917539 \\
\hline C & -3.167002 & -2.677911 & 0.589411 & $\mathrm{H}$ & 3.766098 & -2.507969 & 3.730259 \\
\hline $\mathrm{C}$ & -3.194119 & -3.265746 & 1.868325 & $\mathrm{H}$ & 2.397679 & -4.013007 & 4.376825 \\
\hline C & -3.985038 & -0.445924 & 1.293081 & $\mathrm{H}$ & 5.482921 & -0.969325 & 3.032489 \\
\hline C & -1.103624 & -4.450826 & 1.446366 & $\mathrm{H}$ & 7.145972 & 0.232333 & 2.458559 \\
\hline C & -2.182827 & -4.129312 & 2.289553 & $\mathrm{H}$ & -5.877885 & 4.745738 & 2.991084 \\
\hline
\end{tabular}




\begin{tabular}{|c|c|c|c|c|c|c|c|}
\hline $\mathrm{C}$ & 3.006275 & -4.740964 & 2.431581 & $\mathrm{H}$ & -2.976640 & 0.767002 & 3.586482 \\
\hline $\mathbf{C}$ & 0.216582 & -4.925757 & 1.926559 & $\mathrm{H}$ & -3.361055 & 2.305090 & 5.480912 \\
\hline C & 0.699809 & -4.507451 & 3.179744 & $\mathrm{Cl}$ & -4.904753 & -4.713468 & -5.687811 \\
\hline C & 4.347547 & -4.106348 & 2.397156 & $\mathrm{Cl}$ & -4.901511 & 4.715649 & 5.688111 \\
\hline $\mathrm{C}$ & 4.511012 & -2.858643 & 3.025465 & $\mathrm{H}$ & -2.124103 & 2.739728 & 1.303231 \\
\hline C & 2.065596 & -4.430296 & 3.431895 & $\mathrm{H}$ & -5.506912 & 3.191728 & 1.099359 \\
\hline \multicolumn{8}{|c|}{ Oligomer of PS1 } \\
\hline C & -3.303468 & -4.633769 & -2.239146 & $\mathrm{H}$ & -2.796584 & -5.023947 & -3.115965 \\
\hline $\mathrm{C}$ & -4.095792 & -5.493064 & -1.462317 & $\mathrm{H}$ & -5.340907 & -5.596758 & 0.294194 \\
\hline $\mathbf{C}$ & -4.696648 & -4.964349 & -0.308088 & $\mathrm{H}$ & -2.466837 & -2.675013 & -2.476561 \\
\hline $\mathbf{C}$ & -3.118556 & -3.303712 & -1.878120 & $\mathrm{H}$ & 5.916910 & -1.021063 & -2.975693 \\
\hline $\mathrm{C}$ & 5.955605 & 0.024484 & -3.258411 & $\mathrm{H}$ & 7.619259 & -1.668489 & -1.846002 \\
\hline C & 7.615774 & -0.937342 & -1.044089 & $\mathrm{H}$ & 4.203558 & -0.173809 & -4.445182 \\
\hline C & 4.970476 & 0.511533 & -4.103351 & $\mathrm{H}$ & 2.875039 & 0.677763 & -5.902639 \\
\hline $\mathbf{C}$ & 2.550056 & 1.571320 & -5.379447 & $\mathrm{H}$ & -1.725310 & 1.765134 & -5.316220 \\
\hline C & -1.694748 & 2.043715 & -4.266899 & $\mathrm{H}$ & 0.487546 & 1.046331 & -5.576686 \\
\hline C & 1.187289 & 1.793611 & -5.216055 & $\mathrm{H}$ & -3.498173 & 0.975472 & -3.827667 \\
\hline C & -2.705469 & 1.594240 & -3.417449 & $\mathrm{H}$ & -3.462454 & -0.690020 & -2.347785 \\
\hline C & -3.717002 & -2.777662 & -0.722286 & $\mathrm{H}$ & -4.994908 & -3.247408 & 0.943633 \\
\hline C & -3.491408 & -0.370923 & -1.311720 & $\mathrm{H}$ & -1.626923 & -2.965279 & 0.530935 \\
\hline C & -4.510959 & -3.636829 & 0.054437 & $\mathrm{H}$ & 0.119932 & -3.748836 & 1.997894 \\
\hline C & -1.692646 & -2.722873 & 1.582950 & $\mathrm{H}$ & 1.295979 & -4.744435 & 3.544954 \\
\hline C & -3.543331 & -1.361635 & -0.326675 & $\mathrm{H}$ & 5.833044 & -3.822425 & 4.127472 \\
\hline C & -0.696526 & -3.180214 & 2.427829 & $\mathrm{H}$ & 3.686240 & -4.326087 & 3.746875 \\
\hline C & 1.630462 & -3.850973 & 4.062381 & $\mathrm{H}$ & 7.574373 & -2.978425 & 2.639108 \\
\hline C & 5.849621 & -2.763680 & 3.887222 & $\mathrm{H}$ & 7.540306 & -2.454476 & 0.454121 \\
\hline $\mathrm{C}$ & 2.994039 & -3.624072 & 4.199654 & $\mathrm{H}$ & 7.597950 & 2.919973 & -2.637715 \\
\hline $\mathrm{C}$ & 6.842858 & -2.282362 & 3.038339 & $\mathrm{H}$ & 7.559917 & 2.395951 & -0.453340 \\
\hline C & 7.596985 & -1.386631 & 0.270691 & $\mathrm{H}$ & 5.863586 & 3.777555 & -4.126309 \\
\hline C & 7.476869 & 0.429929 & -1.345103 & $\mathrm{H}$ & 3.720911 & 4.297472 & -3.746395 \\
\hline $\mathrm{C}$ & 6.859766 & 0.887048 & -2.614011 & $\mathrm{H}$ & 0.150783 & 3.746517 & -1.997220 \\
\hline C & 6.861392 & 2.229542 & -3.037446 & $\mathrm{H}$ & 1.333927 & 4.733984 & -3.544322 \\
\hline C & 7.607958 & 1.327683 & -0.269930 & $\mathrm{H}$ & -3.506714 & -0.948123 & 3.827469 \\
\hline C & 4.834316 & 1.888539 & -4.351214 & $\mathrm{H}$ & -3.457604 & 0.716681 & 2.347546 \\
\hline C & 5.872109 & 2.718621 & -3.886484 & $\mathrm{H}$ & -1.740282 & -1.751473 & 5.316263 \\
\hline C & 0.715561 & 2.869889 & -4.443957 & $\mathrm{H}$ & 0.477816 & -1.050102 & 5.576766 \\
\hline C & 3.500056 & 2.398267 & -4.751969 & $\mathrm{H}$ & 4.202430 & 0.141343 & 4.444018 \\
\hline C & 3.023382 & 3.600815 & -4.199264 & $\mathrm{H}$ & 2.868075 & -0.699718 & 5.902584 \\
\hline C & -0.602014 & 2.776560 & -3.771100 & $\mathrm{H}$ & 5.922699 & 0.975183 & 2.974773 \\
\hline C & -0.670235 & 3.184616 & -2.427307 & $\mathrm{H}$ & 7.631665 & 1.609337 & 1.846800 \\
\hline C & 1.661582 & 3.838086 & -4.061909 & $\mathrm{H}$ & -5.294535 & 5.638760 & -0.295311 \\
\hline C & -2.665196 & 1.849424 & -2.034090 & $\mathrm{H}$ & -2.446187 & 2.693309 & 2.476905 \\
\hline C & -1.669989 & 2.735005 & -1.582594 & $\mathrm{H}$ & -2.756884 & 5.044864 & 3.116208 \\
\hline C & -3.354158 & -0.967626 & 1.024156 & $\mathrm{H}$ & -1.602359 & 2.976501 & -0.530488 \\
\hline C & -3.345873 & 0.993369 & -1.024333 & $\mathrm{H}$ & -4.967624 & 3.286648 & -0.944622 \\
\hline $\mathrm{C}$ & -3.532318 & 1.388905 & 0.326423 & $\mathrm{C}$ & -4.287598 & -6.910306 & -1.844041 \\
\hline $\mathrm{C}$ & -2.680653 & -1.829110 & 2.034109 & $\mathrm{C}$ & -4.398232 & -7.284964 & -3.192703 \\
\hline C & -2.718961 & -1.573293 & 3.417427 & $\mathrm{C}$ & -4.362308 & -7.915296 & -0.866259 \\
\hline
\end{tabular}




\begin{tabular}{llllllll}
\hline $\mathbf{C}$ & -3.488777 & 0.397804 & 1.311482 & $\mathrm{C}$ & -4.576395 & -8.618946 & -3.551700 \\
$\mathbf{C}$ & -0.624979 & -2.772208 & 3.771454 & $\mathrm{H}$ & -4.370884 & -6.519043 & -3.961304 \\
$\mathbf{C}$ & -1.711893 & -2.030571 & 4.267019 & $\mathrm{C}$ & -4.542506 & -9.249108 & -1.224780 \\
$\mathbf{C}$ & 3.479874 & -2.425109 & 4.752154 & $\mathrm{H}$ & -4.251335 & -7.648624 & 0.179982 \\
$\mathbf{C}$ & 0.691861 & -2.875524 & 4.444297 & $\mathrm{C}$ & -4.649862 & -9.607223 & -2.569250 \\
$\mathbf{C}$ & 1.171816 & -1.802758 & 5.216226 & $\mathrm{H}$ & -4.667834 & -8.886015 & -4.600237 \\
$\mathbf{C}$ & 4.817975 & -1.925637 & 4.351303 & $\mathrm{H}$ & -4.589750 & -10.011517 & -0.453036 \\
$\mathbf{C}$ & 4.964405 & -0.549794 & 4.102802 & $\mathrm{H}$ & -4.789722 & -10.646823 & -2.848765 \\
$\mathbf{C}$ & 2.536240 & -1.590842 & 5.379539 & $\mathrm{C}$ & -4.231553 & 6.943494 & 1.843531 \\
$\mathbf{C}$ & 6.851483 & -0.940049 & 2.614468 & $\mathrm{C}$ & -4.339695 & 7.319047 & 3.192146 \\
$\mathbf{C}$ & 5.953460 & -0.070478 & 3.258046 & $\mathrm{C}$ & -4.297451 & 7.949071 & 0.865722 \\
$\mathbf{C}$ & 7.472692 & -0.487846 & 1.345804 & $\mathrm{C}$ & -4.506950 & 8.654458 & 3.551068 \\
$\mathbf{C}$ & 7.622645 & 0.878263 & 1.044860 & $\mathrm{H}$ & -4.319042 & 6.552918 & 3.960749 \\
$\mathbf{C}$ & -4.480967 & 3.672024 & -0.055141 & $\mathrm{C}$ & -4.466744 & 9.284329 & 1.224170 \\
$\mathbf{C}$ & -4.655875 & 5.001024 & 0.307318 & $\mathrm{H}$ & -4.188197 & 7.681483 & -0.180465 \\
$\mathbf{C}$ & -3.694555 & 2.806305 & 0.721981 & $\mathrm{C}$ & -4.571756 & 9.643316 & 2.568592 \\
$\mathbf{C}$ & -3.092394 & 3.327372 & 1.878146 & $\mathrm{H}$ & -4.596650 & 8.922274 & 4.599566 \\
$\mathbf{C}$ & -4.051298 & 5.524724 & 1.461886 & $\mathrm{H}$ & -4.507297 & 10.047110 & 0.452412 \\
$\mathbf{C}$ & -3.266509 & 4.658897 & 2.239114 & $\mathrm{H}$ & -4.703103 & 10.684040 & 2.848051 \\
\hline
\end{tabular}

\section{Reference References.}

(S1) Akita, M.; Saito, M.; Osaka, I.; Koganezawa, T.; Takimiya, K. RSC Adv. 2016, 6, 16437-16447.

(S2) Huang, Q.; Zhuang, G. L.; Jia, H. X.; Qian, M. M.; Cui, S. S.; Yang, S. F.; Du, P. W. Angew. Chem., Int. Ed. 2019, 58, 6244-6249.

(S3) Gaussian 09, Revision A.1, M. J. Frisch, G. W. Trucks, H. B. Schlegel, et.al. Gaussian, Inc., Wallingford CT, 2009.

(S4) S. Grimme, S. Ehrlich, and L. Goerigk, J. Comp. Chem. 2011, 32, 1456.

(S5) B. Menucci, J. Tomasi, J. Phys. Chem. A, 2002, 106, 6102.

(S6) Delley, B. J. Chem. Phys. 1990, 92, 508-517.

(S7) Delley, B. J. Chem. Phys. 1991, 94, 7245-7250.

(S8) Delley, B. J. Chem. Phys. 2000, 113, 7756-7764

(S9) A. K. Rappe, C. J. Casewit, K. S. Colwell, W. A. Goddard, W. M. Skiff, J. Am. Chem. Soc. 1992, 114, 10024-10035.

(S10) S. Nosé, J. Chem. Phys. 1984, 81, 511-519.

(S11) G. Lippert, J. Hutter, M. A. Parrinello, Mol. Phys. 1997, 92, 477-488.

(S12) J. VandeVondele, J. Hutter, J. Chem. Phys. 2007, 127, 114105

(S13) S. Goedecker, M. Teter, J. Hutter, Phys. Rev. B: Condens. Matter Mater. Phys. 1996, 54, 1703-1710.

(S14) J. VandeVondele, J. Hutter, J. Chem. Phys. 2003, 118, 4365-4369. 